Review

\title{
Photoynthetic and productive increase in tomato plants treated with strobilurins and carboxamides for the control of Alternaria solani
}

\author{
Janaina Marek $^{\mathrm{a}, *}$, Dione de Azevedo ${ }^{\mathrm{a}}$, Elizabeth Orika Ono ${ }^{\mathrm{b}}$, João Domingos Rodrigues ${ }^{\mathrm{b}}$, \\ Cacilda Marcia Duarte Rios Faria ${ }^{\mathrm{a}}$ \\ ${ }^{\text {a } U n i v e r s i d a d e ~ E s t a d u a l ~ d o ~ C e n t r o-O e s t e ~(U N I C E N T R O), ~ C a m p u s ~ C e d e t e g, ~ D e p a r t a m e n t o ~ d e ~ A g r o n o m i a, ~ C E P: ~ 85040-080, ~ G u a r a p u a v a, ~ P R, ~ B r a z i l ~}$ \\ ${ }^{\mathrm{b}}$ Instituto de Biociências, Universidade Estadual Paulista “Júlio de Mesquita Filho" (UNESP), Campus de Botucatu, Departamento de Botânica, CEP: 18618-970, \\ Botucatu, SP, Brazil
}

\section{A R T I C L E IN F O}

\section{Keywords:}

Solanum lycopersicum

Physiological effect

Photosynthesis

Fungicides

\begin{abstract}
A B S T R A C T
During two years (2015 and 2016), an experiment was carried out to investigate the effects of the application of strobilurin and carboxamides on the photosynthetic efficiency and yield of tomato plants inoculated with $A$. solani grown in greenhouse in southern Brazil. The experimental design was randomized blocks with five replicates and seven treatments: inoculated control (water + inoculum), absolute control (water), boscalid $\left(0.075 \mathrm{~g} \mathrm{~L}^{-1}\right)$, boscalid $\left(0.100 \mathrm{~g} \mathrm{~L}^{-1}\right)+$ kresoxim-methyl $\left(0.050 \mathrm{~g} \mathrm{~L}^{-1}\right)$, pyraclostrobin $\left(0.100 \mathrm{~g} \mathrm{~L}^{-1}\right)$, fluxapyroxad $\left(0.058 \mathrm{~g} \mathrm{~L}^{-1}\right)+$ pyraclostrobin $\left(0.116 \mathrm{~g} \mathrm{~L}^{-1}\right)$ and methyl $\left(1.100 \mathrm{~g} \mathrm{~L}^{-1}\right)+$ pyraclostrobin $(0.100 \mathrm{~g}$ $\mathrm{L}^{-1}$ ), applied at 15 days after transplantation, at intervals of 15 days, totaling 6 applications. The effect on plant development was evaluated by plant height, leaf area, fresh and dry mass of leaves, stem and roots. To verify the photosynthetic efficiency, gas exchange, chlorophyll $a$ fluorescence, content of photosynthetic pigments, nitrate reductase enzyme activity, carbohydrate content and yield were evaluated. All fungicides positively affected the evaluated parameters, improving photosynthetic efficiency and fruit production, in addition to providing efficient disease control. However, treatments using fluxapyroxad with pyraclostrobin, followed by metiram with pyraclostrobin stood out for promoting high photochemical yield due to the higher levels of photosynthetic pigments, activity of the nitrate reductase enzyme and, consequently, increase in the synthesis and translocation of photoassimilates. These results demonstrate the benefits of the use of these agrochemicals in the control of $A$. solani in tomato.
\end{abstract}

\section{Introduction}

Due to the growing expansion of tomato crop (Solanum lycopersicum L.), several phytosanitary problems have emerged, among them, many diseases, including black pint, caused by fungus Alternaria solani, capable of causing severe damages in the culture (Töfoli et al., 2014). Among strategies to control fungal diseases, the application of fungicides is the most frequent and vital for effective control (Petit et al., 2012; Bag et al., 2016). Many fungicides are registered for the control of black pint in tomato, such as those belonging to the chemical groups of strobilurins and carboxamides.

Fungicides of the strobilurin group, such as kresoxim-methyl and pyraclostrobin, act to inhibit mitochondrial respiration, blocking electron transfer in complex III and interfering in ATP production (Kanungo and Joshi, 2014). Similar to the mode of action of strobilurins, carboxamides, such as boscalid and fluxapyroxad, act on complex II of mitochondrial respiration, inhibiting succinate dehydrogenase enzyme (SDHI) (Frac Code List (C), 2017), reducing the respiratory process and blocking the energy supply of the fungus (Van Dingenen et al., 2017).

Since the advent of these molecules, primarily strobilurins in the 1980 s and more recently carboxamides, many researchers have observed that in addition to effective disease control, there are simultaneous effects on plant physiology, increasing crop yield (Fagan et al., 2010; Diaz-Espejo et al., 2012; Kanungo and Joshi, 2014; Van Dingenen et al., 2017). Numerous studies have shown positive effects of the application of these molecules on different crops such as soybeans, beans, corn, bananas, carrots, sunflowers, cucumbers, melons, tomatoes and grapes (Lima et al., 2009; Tsumanuma et al., 2010; Lima et al., 2012; Diaz-Espejo et al., 2012; Colombari et al., 2015; Ramos et al., 2015; Jadoski et al., 2015; Tsialtas et al., 2017; Macedo et al., 2017; Amaro

\footnotetext{
* Corresponding author.

E-mail addresses: janainamarek@gmail.com (J. Marek), dione.azevedo@hotmail.com (D. de Azevedo), eoono@ibb.unesp.br (E.O. Ono), mingo@ibb.unesp.br (J.D. Rodrigues), criosfaria@hotmail.com (C.M.D.R. Faria).
} 
et al., 2018). As reported in these studies, the main effects observed are the activation of important enzymes in cell metabolism, such as NADHnitrate reductase enzyme, increasing the assimilation of nitrogen and its incorporation in different vital molecules of the plant, such as chlorophyll, also reducing ethylene production, justifying the green effect, since in addition to the higher content of pigments, senescence is delayed. Another effect observed is the increase in $\mathrm{CO}_{2}$ assimilation efficiency, increasing the photosynthetic rate and reducing the respiratory rate, culminating in higher net photosynthesis and productivity.

However, there are studies showing divergent results, as that by Petit et al. (2012), in which the application of strobilurins and even of fungicides of other chemical groups may negatively affect plant physiology and metabolism. These authors, after carrying out a large compilation of studies, pointed out that the intensity of the effect provided by different fungicides depends on the sensitivity of the plant species, vegetative phase, type and dose of the evaluated fungicide and environmental conditions. In addition, they reported that the disturbances caused by the use of fungicides in the cellular homeostasis of the plant can encode a situation of stress, generating metabolic expenditure, affecting metabolism.

In fact, there are reports in literature in which the application of pyraclostrobin did not affect the photosynthetic efficiency in corn plants in the absence of diseases (Junqueira et al., 2017) and of four soybean varieties (Swoboda and Pedersen, 2009). The final yield of common bean was not affected by the application of azoxystrobin and pyraclostrobin (Mahoney and Gillard, 2014). The application of azoxystrobin in wheat, barley and soybean (Nason et al., 2007), rice (Debona et al., 2016) and Japanese cucumber (Amaro et al., 2018), decreased the net $\mathrm{CO}_{2}$ assimilation rate, transpiration, stomatal conductance and internal carbon dioxide concentration leading to a decrease in the photosynthetic efficiency of these plants.

Analyzing the world agricultural scenario and the constant search for high productivity, further studies should be carried out to verify the effects of these fungicides, promoting physiological effects on different crops and growing conditions.

The objective of this work was to evaluate the effects of the application of boscalid, kresoxim-methyl with boscalid, pyraclostrobin, fluxapyroxad with pyraclostrobin and metiram with pyraclostrobin on the photosynthetic efficiency and productivity of plants of hybrid tomato Conquistador in a greenhouse.

\section{Material and methods}

\subsection{Plant material and cultivation system}

Experiments were conducted in the period from January to May, in the years 2015 and 2016, in greenhouse belonging to the Department of Agronomy, "Universidade Estadual do Centro-Oeste (Unicentro)", Cedeteg Campus, municipality of Guarapuava, State of Paraná, Brazil. The study site is located at latitude $25^{\circ} 23^{\prime} 36^{\prime \prime} \mathrm{S}$ and longitude $51^{\circ} 27^{\prime} 1^{\prime \prime}$ $\mathrm{W}$ and $1,025 \mathrm{~m}$ above sea level, with humid mesothermic subtropical climate.Seeds of hybrid tomato Conquistador cv. (Sakata Seeds Sudamérica Ltda.) were seeded in polypropylene trays with 128 cells, filled with commercial substrate (Carolina Soil ${ }^{\circ}$ ) on December 2, 2015 (experiment I) and 2016 (experiment II). Transplanting was carried out 34 days after sowing in $10 \mathrm{dm}^{3}$ pots filled with typical Dusky Dystroferric Latosol (Embrapa - Empresa Brasileira de Pesquisa Agropecuária, 2013) with 1.0 x $0.5 \mathrm{~m}$ spacing. Soil correction and fertilization were carried out based on its chemical analysis. Throughout the crop cycle, drip irrigation was performed and weed control was manually performed and pest control was carried out according to recommendations for the crop.

Plants were conducted with a stem along the cycle, individually and vertically tutored. Shoots were removed when they reached $3-5 \mathrm{~cm}$ in length. Plants were cultivated up to the fifth bunch of fruits, when apical pruning was performed.

\subsection{Experimental design and treatments}

The experimental design was randomized blocks with 7 treatments and 5 replicates, each plot being composed of 4 plants. Treatments were the following: inoculated control (water + inoculum); absolute control (water); boscalid $\left(0.075 \mathrm{~g} \mathrm{~L}^{-1}\right)$; boscalid $\left(0.100 \mathrm{~g} \mathrm{~L}^{-1}\right)+$ kresoximmethyl $\left(0.050 \mathrm{~g} \mathrm{~L}^{-1}\right)$; pyraclostrobin $\left(0.100 \mathrm{~g} \mathrm{~L}^{-1}\right)$; fluxapyroxad $\left(0.058 \mathrm{~g} \mathrm{~L}^{-1}\right)+$ pyraclostrobin $\left(0.116 \mathrm{~g} \mathrm{~L}^{-1}\right)$ and metiram $(1.100 \mathrm{~g}$ $\left.\mathrm{L}^{-1}\right)+$ pyraclostrobin $\left(0.100 \mathrm{~g} \mathrm{~L}^{-1}\right)$.

The first application was performed 15 days after transplanting (DAT) and the others in 15-day intervals, totaling six applications in the entire plant using a pressurized $\mathrm{CO}_{2}$ manual sprayer $\left(0.3 \mathrm{kgf} / \mathrm{cm}^{2}\right)$ and conical nozzles, using plastic curtain between treatments to avoid drift. Physiological and biochemical evaluations were performed after each treatment application.

\subsection{Isolation and inoculation of the pathogen: Alternaria solani}

A. solani isolate was obtained from leaf lesions of tomato plants at the Cedeteg University campus. The fungus was cultivated in PAD (potato agar dextrose) medium and the inoculation of plants was performed $24 \mathrm{~h}$ after the first application of treatments (16 DAT) with suspension containing $1 \times 10^{4}$ conidia $\mathrm{mL}^{-1}$.

Plants, with the exception of the absolute control treatment, were inoculated $24 \mathrm{~h}$ after the first application of the treatments (16 DAT) with suspension containing $1 \times 10^{4}$ conidia $\mathrm{mL}^{-1}$, on both sides of the leaflets of all the leaves of the plant, with hand spray until that drops were formed and began to drip from the ends of the leaflets. After inoculation of the plants the humidity and temperature of the greenhouse were monitored so that the ideal conditions for the development of the pathogen were maintaine.

\subsection{Properties evaluated}

\subsubsection{Plant development analysis}

Plant height evaluations were performed at 14 (before the first application of treatments) and at 21, 28, 35, 42, 49, 56 and 65 DAT (days after transplanting). The last evaluation occurred at 65 DAT, at which time apical pruning was performed. For measurements, a graduated ruler was used and the results were expressed in $\mathrm{cm}^{-1}$ plant.

At 120 DAT (harvest term), five plants from each treatment were collected, separated in leaf, stem and root, and fresh and dry mass was measured. The dry mass was obtained by drying leaves, stems and roots in a forced circulation oven at constant temperature of $60{ }^{\circ} \mathrm{C}$ until reaching constant mass, and results were expressed in grams (g). The leaf area was measured using LiCor ${ }^{\circledR}$ Area Meter, Model LI-3100 Area Meter and results were expressed in square centimeters $\left(\mathrm{cm}^{2}\right)$.

\subsubsection{Gas exchanges and chlorophyll a fluorescence}

Gas exchange and chlorophyll $a$ fluorescence evaluations were performed at 34 and 94 DAT (5th day after the second and sixth treatments, respectively), in completely expanded leaves, located in the middle third of the plant. Readings were performed in duplicate, from 9:00 AM to 11:00 AM. For the readings of gas exchanges, equipment with open system with photosynthesis with $\mathrm{CO}_{2}$ analyzer and water vapor by infrared radiation ("Infra Red Gas Analyser - IRGA", model LI6400XT, LI-COR) was used and results were calculated from the difference between the $\mathrm{CO}_{2}$ concentration and the reference air water vapor (value present in the chamber without leaves) and the sample (value with the presence of leaves in the chamber), obtaining the water vapor and $\mathrm{CO}_{2}$ concentrations that were released (transpiration - water vapor) and assimilated $\left(\mathrm{CO}_{2}\right.$ assimilation) through the stomata.

The characteristics of gas exchanges analyzed were: net $\mathrm{CO}_{2}$ assimilation rate $\left(A_{\text {net }}, \mu \mathrm{mol} \mathrm{CO}_{2} \mathrm{~m}^{-2} \mathrm{~s}^{-1}\right)$, transpiration rate $(E, \mathrm{mmol}$ water vapor $\left.\mathrm{m}^{-2} \mathrm{~s}^{-1}\right)$, stomatal conductance $\left(g s, \mathrm{~mol} \mathrm{~m}^{-2} \mathrm{~s}^{-1}\right)$ and internal $\mathrm{CO}_{2}$ concentration in leaves $\left(\mathrm{Ci}, \mu \mathrm{mol} \mathrm{CO}_{2} \mathrm{~mol}^{-1}\right.$ air). These 
characteristics were calculated by the data analysis program present in the gas exchange measuring equipment, which uses the general gas exchange equation of Von Caemmerer and Farquhar (1981).

The water use efficiency $\left(W U E, \mu \mathrm{mol} \mathrm{CO}_{2}\left(\mathrm{mmol} \mathrm{H}_{2} \mathrm{O}\right)^{-1}\right)$ was determined by the relationship between $\mathrm{CO}_{2}$ assimilation rate and transpiration rate and the carboxylation efficiency of the ribulose 1,5-diphosphate carboxylase (Rubisco) enzyme, which was determined by the relationship between $\mathrm{CO}_{2}$ assimilation rate and internal $\mathrm{CO}_{2}$ concentration in leaves $\left(A_{\text {net }} / C_{i}\right)$.

The chlorophyll $a$ fluorescence readings were performed with a Portable Chlorophyll Fluorometer (PAM-2500), simultaneously with gas exchange measures. Slow kinetics measurements were performed, with leaf adaptation to dark for $20 \mathrm{~min}$ (so that all reaction centers were open, with ability to receive electrons). Basal fluorescence $\left(F_{O}\right)$ and maximum fluorescence $\left(F_{m}\right)$ parameters were obtained, from which fluorescence $\left(F_{v}\right)$ and maximum quantum yield of PSII $\left(F_{v} / F_{m}\right)$ were calculated. The responses of effective photochemical quantum yield of PSII, Y(II) and relative electron transfer rate (ETR) were also obtained. Fluorescence data obtained were automatically stored in the PAM memory and later transferred to the computer via Wincontrol computer software.

\subsubsection{Activity of the nitrate reductase enzyme and content of} photosynthetic pigments

To evaluate the activity of the nitrate reductase enzyme (NR, EC 1.6.6.1) and the content of photosynthetic pigments, 8 leaves were collected at 15, 20, 35, 50, 65, 80, 95 and 110 DAT, corresponding to the following moments:

- Time $0 \mathrm{~h}$ before treatment (15 DAT);

- 5th day after the first treatment application (20 DAT);

- 5th day after the second treatment application (35 DAT);

- 5th day after the third treatment application (50 DAT);

- 5th day after the fourth treatment application (65 DAT);

- 5th day after the fifth treatment application (80 DAT);

- 5th day after the sixth and last treatment applications (95 DAT);

- 15 days after the last treatment application (105 DAT).

For the determination of the activity of the NR enzyme, leaves were collected between 10 and $11 \mathrm{~A} \mathrm{M}$, packed in foil and stored in styrofoam box with ice (keeping the material fresh, not freezing). Subsequently, the collected material was taken to the laboratory and the activity of the NR enzyme was determined according to methodology proposed by Streeter and Bosler (1972), where $1 \mathrm{~g}$ of sample was weighed into light protected tubes (paper coated aluminum). Then, $8 \mathrm{~mL}$ of buffer composed of $0.1 \mathrm{M}$ phosphate buffer (KPi) $\mathrm{pH} 7.5+0.2 \mathrm{M} \mathrm{KNO}_{3}$ were added, the reaction was conducted at $37^{\circ} \mathrm{C}$ for $1 \mathrm{~h}$. After this period, $1 \mathrm{~mL}$ of $1 \%$ sulfanilamide in $1.5 \% \mathrm{HCl}+1 \mathrm{~mL}$ of $0.2 \% \alpha$-Naphthyl was added. After $5 \mathrm{~min}$, the sample was filtered in cotton and read in spectrophotometer at $540 \mathrm{~nm}$. Samples were collected and analyzed on the same day of collection and the activity of the NR enzyme was expressed in $\mu \mathrm{g} \min ^{-1}$ of fresh nitrite mass $\mathrm{g}^{-1}$.

To determine the pigment content, collection occurred simultaneously with the collection to determine the activity of the NR enzyme, however, after collection, leaves were immediately frozen in liquid nitrogen to stop all reactions. The content of photosynthetic pigments was determined by the spectrophotometric method proposed by Lichtenthaler and Wellburn (1983), using $0.030 \mathrm{~g}$ of macerated vegetable material with $8 \mathrm{~mL}$ of $80 \%$ acetone and $0.01 \mathrm{~g}$ of calcium carbonate $\left(\mathrm{Ca}\left(\mathrm{CO}_{3}\right)_{2}\right)$ and centrifuged for $20 \mathrm{~min}$ at $13,500 \mathrm{~g}$. The supernatant was read in spectrophotometer at wavelengths of 470.0, 646.8 and $663.2 \mathrm{~nm}$.

For calculations of the content of chlorophyll pigments (chl $a, b$ and total) the following formulas were used:

Chlorophyll $a(\mu \mathrm{g} / \mathrm{mL})=12.1 \mathrm{~A}_{663}-2.81 \mathrm{~A}_{646}$
Chlorophyll $b(\mu \mathrm{g} / \mathrm{mL})=20.13 \mathrm{~A}_{646}-5.03 \mathrm{~A}_{663}$

Chls total $=17.76 \mathrm{~A}_{646.6}+7.34 . \mathrm{A}_{663.6}$

Carotenoids $(\mu \mathrm{g} / \mathrm{mL})=\left(\left(1000 \mathrm{~A}_{470-3.27}[\mathrm{Chl} a]-104[\mathrm{Chl} b]\right) / 229\right.$.

The levels of chlorophyll and carotenoid pigments were expressed as $\mu \mathrm{g} \mathrm{mL}^{-1} \mathrm{~g}$ fresh mass $^{-1}$.

\subsubsection{Carbohydrate analysis}

To determine the carbohydrate content (reducing sugars and soluble sugars), two destructive evaluations were carried out during plant development, the first was carried out at 50 DAT and the second at 120 DAT (the last day of harvest). Five plants were collected per treatment, which were separated into leaves, stem and fruits and the carbohydrate content was determined in these organs. The extraction of soluble sugars was performed according to methodology proposed by Garcia et al. (2006) using $0.1 \mathrm{~g}$ of fresh plant material.

The extract obtained was separated into microtubes and stored at $-20^{\circ} \mathrm{C}$ until the determination of carbohydrates. For the quantification of total soluble sugars, the methodologies of Morris (1948) and Yemm and Willis (1954) were used. Reading was performed in spectrophotometer at $620 \mathrm{~nm}$, using standard curve of glucose solution. The content of total soluble sugars was expressed as $\mathrm{mg} \mathrm{g}^{-1}$ of fresh mass. The quantification of reducing sugars was performed according to methodology proposed by Miller (1959). Reading was performed in spectrophotometer at $540 \mathrm{~nm}$, using standard curve of glucose solution. Reducing sugars were expressed as $\mathrm{mg} \mathrm{g}^{-1}$ of fresh mass.

\subsubsection{Assessment of the severity of Alternaria solani}

The severity of the disease was evaluated at the onset of the first symptoms, occurring five days after inoculation (20 DAT). The evaluations were carried out in five previously identified leaflets, by three evaluators, in 10 plants per treatment, at intervals of 7 days. Eight severity assessments were performed from January 28 to March 17 in both experiments. For the severity evaluation, the diagrammatic scale of de Azevedo (1997) was used. The methodology proposed by Campbell and Madden (1990) was used to calculate the area under the progression curve of the disease (AUPCD).

\subsubsection{Production}

In the experiment conducted in 2015, fruit harvest began on March 27, 2015 (79 DAT) and extended until May 5, 2015 (118 DAT), while experiment conducted in 2016, fruit harvest started on March 30, 2016 (82 DAT) and extended until May 7, 2016 (120 DAT). The harvest period comprised on average 37 days and was performed weekly, as fruits reached the stage of light red maturation. All fruits were weighed in analytical scale, and results were expressed in grams (g); diameter measured with pachymeter and values expressed in millimeters ( $\mathrm{mm}$ ).

Total and commercial production of tomato fruits $\left(\mathrm{kg} \mathrm{m}^{-2}\right)$, number of fruits $\mathrm{m}^{-2}$, average fruit mass $(\mathrm{g})$, diameter and length of fruits were evaluated. To evaluate production, fruits were selected as "non commercial" and "commercial", considering fruits with diameter less than $40 \mathrm{~mm}$ as "non commercial" and greater than $40 \mathrm{~mm}$ and without defects (symptoms of diseases, plagues, physiological disorders and/or physical damages) as "commercial".

\subsection{Statistical analysis}

Data normality was verified by the Shapiro-Wilk test and homogeneity of variance by Cochran C test, before each parametric statistical test and analysis of variance (ANOVA), and means were compared by the Tukey test, both at 5\% significance level. Gas exchange and chlorophyll $a$ fluorescence data were not normal and were transformed by the Box-Cox method. Meanwhile, data on non-commercial fruit percentage were transformed by $\sqrt{ } \mathrm{x}(\%)$. All statistical tests were 
Table 1

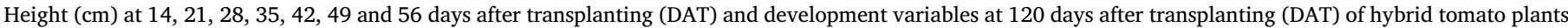

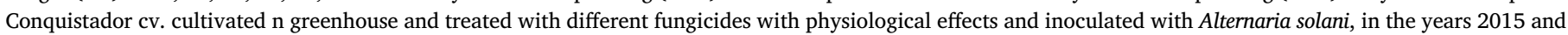
2016.

\begin{tabular}{|c|c|c|c|c|c|c|c|c|c|c|c|c|c|}
\hline \multicolumn{14}{|l|}{2015} \\
\hline \multirow[t]{3}{*}{ Treatments } & \multicolumn{7}{|c|}{ Plant height $(\mathrm{cm})$} & \multicolumn{6}{|c|}{ Development variables } \\
\hline & \multicolumn{7}{|c|}{ Days after transplanting (DAT) } & \multirow[t]{2}{*}{ Leaf area $\left(\mathrm{cm}^{2}\right)$} & \multirow{2}{*}{$\begin{array}{l}\text { Fresh leaf } \\
\text { mass }(g)\end{array}$} & \multirow{2}{*}{$\begin{array}{l}\text { Dry leaf } \\
\text { mass }(g)\end{array}$} & \multirow{2}{*}{$\begin{array}{l}\text { Fresh stem } \\
\text { mass }(\mathrm{g})\end{array}$} & \multirow{2}{*}{$\begin{array}{l}\text { Dry stem } \\
\text { mass }(g)\end{array}$} & \multirow{2}{*}{$\begin{array}{l}\text { Fresh root } \\
\text { mass }(\mathrm{g})\end{array}$} \\
\hline & 14 & 21 & 28 & 35 & 42 & 49 & 56 & & & & & & \\
\hline $\begin{array}{l}\text { Inoculated control } \\
\quad \text { (inoculum }+ \text { water) }\end{array}$ & $26.3 \mathrm{a}$ & $35.5 \mathrm{c}$ & $42.3 c$ & $65.9 c$ & $85.6 \mathrm{c}$ & $120.8 \mathrm{c}$ & $167.5 b$ & $3298.32 \mathrm{e}$ & $111.65 \mathrm{e}$ & $17.26 \mathrm{e}$ & $418.99 c$ & $42.32 \mathrm{c}$ & $60.18 b$ \\
\hline Absolute control (water) & $27.6 \mathrm{a}$ & $33.7 \mathrm{c}$ & $45.8 \mathrm{c}$ & $62.8 \mathrm{c}$ & $86.4 \mathrm{c}$ & $124.2 \mathrm{c}$ & $166.2 b$ & $6247.84 d$ & $211.84 d$ & $21.03 d$ & $423.56 c$ & $44.51 \mathrm{c}$ & $63.93 b$ \\
\hline Boscalid $\left(0.075 \mathrm{~g} \mathrm{~L}^{-1}\right)$ & $26.3 a$ & $39.2 \mathrm{~b}$ & $49.6 b$ & $69.9 \mathrm{~b}$ & $92.3 b$ & $139.6 \mathrm{~b}$ & $174.2 \mathrm{a}$ & $8141.22 c$ & $275.37 c$ & $26.41 \mathrm{c}$ & $443.25 b$ & $51.47 \mathrm{~b}$ & $81.03 \mathrm{a}$ \\
\hline $\begin{array}{l}\text { Boscalid }\left(0.100 \mathrm{~g} \mathrm{~L}^{-1}\right) \\
\quad+\text { Kresoxim methyl } \\
\left(0.050 \mathrm{~g} \mathrm{~L}^{-1}\right)\end{array}$ & $27.2 \mathrm{a}$ & $38.6 \mathrm{~b}$ & $50.3 b$ & $68.3 \mathrm{~b}$ & $93.2 \mathrm{~b}$ & $140.2 b$ & $174.6 \mathrm{a}$ & $8037.21 \mathrm{c}$ & $270.12 c$ & $26.97 \mathrm{c}$ & $440.24 b$ & $48.94 b$ & $78.91 \mathrm{a}$ \\
\hline Pyraclostrobin $\left(0.100 \mathrm{~g} \mathrm{~L}^{-1}\right)$ & $27.0 \mathrm{a}$ & $39.4 \mathrm{~b}$ & $52.4 \mathrm{~b}$ & $69.9 b$ & $95.6 \mathrm{~b}$ & $141.2 b$ & $175.2 \mathrm{a}$ & $8119.04 c$ & $273.98 \mathrm{c}$ & $26.24 \mathrm{c}$ & $442.08 b$ & $49.12 b$ & 79.31a \\
\hline $\begin{array}{l}\text { Fluxapyroxad }\left(0.058 \mathrm{~g} \mathrm{~L}^{-1}\right) \\
\quad+\text { Pyraclostrobin }(0.116 \mathrm{~g} \\
\left.\mathrm{L}^{-1}\right)\end{array}$ & $26.9 \mathrm{a}$ & $41.2 \mathrm{a}$ & $57.6 \mathrm{a}$ & $72.9 \mathrm{a}$ & $106.5 a$ & $152.3 \mathrm{a}$ & $175.6 \mathrm{a}$ & $10,452.11 \mathrm{a}$ & $330.95 a$ & $39.09 a$ & $502.34 \mathrm{a}$ & $56.98 \mathrm{a}$ & $82.01 \mathrm{a}$ \\
\hline $\begin{array}{l}\text { Metiram }\left(1.100 \mathrm{~g} \mathrm{~L}^{-1}\right) \\
\quad+\text { Pyraclostrobin }(0.100 \mathrm{~g} \\
\left.\quad \mathrm{L}^{-1}\right)\end{array}$ & $27.4 \mathrm{a}$ & $40.6 a$ & $55.2 \mathrm{a}$ & $70.1 \mathrm{ab}$ & $104.9 \mathrm{a}$ & $149.7 \mathrm{a}$ & $175.3 a$ & $9914.29 b$ & $309.71 b$ & $30.42 b$ & $495.36 \mathrm{a}$ & $55.09 a$ & $80.96 a$ \\
\hline CV (\%) & 12.4 & 14.5 & 16.4 & 18.7 & 18.1 & 19.2 & 12.5 & 12.65 & 13.45 & 14.72 & 12.35 & 10.84 & 12.72 \\
\hline
\end{tabular}

2016

\begin{tabular}{|c|c|c|c|c|c|c|c|c|c|c|c|c|c|}
\hline \multirow[t]{3}{*}{ Treatments } & \multicolumn{7}{|c|}{ Plant height $(\mathrm{cm})$} & \multicolumn{6}{|c|}{ Development variables } \\
\hline & \multicolumn{7}{|c|}{ Days after transplanting (DAT) } & \multirow[b]{2}{*}{ Leaf area $\left(\mathrm{cm}^{2}\right)$} & \multirow[b]{2}{*}{$\begin{array}{l}\text { Fresh leaf } \\
\text { mass }(g)\end{array}$} & \multirow[b]{2}{*}{$\begin{array}{l}\text { Dry leaf } \\
\text { mass }(g)\end{array}$} & \multirow[b]{2}{*}{$\begin{array}{l}\text { Fresh stem } \\
\text { mass }(g)\end{array}$} & \multirow[b]{2}{*}{$\begin{array}{l}\text { Dry stem } \\
\text { mass }(\mathrm{g})\end{array}$} & \multirow[b]{2}{*}{$\begin{array}{l}\text { Fresh root } \\
\text { mass }(\mathrm{g})\end{array}$} \\
\hline & 14 & 21 & 28 & 35 & 42 & 49 & 56 & & & & & & \\
\hline $\begin{array}{l}\text { Inoculated control } \\
\quad \text { (inoculum + water) }\end{array}$ & $26.8 \mathrm{a}$ & $35.3 c$ & $43.6 c$ & $65.7 \mathrm{c}$ & $90.7 \mathrm{c}$ & $124.1 \mathrm{c}$ & $168.1 \mathrm{~b}$ & $3098.12 \mathrm{e}$ & $108.69 \mathrm{e}$ & $15.86 \mathrm{~d}$ & $401.32 \mathrm{e}$ & $41.28 \mathrm{c}$ & $61.39 b$ \\
\hline Absolute control (water) & $27.9 \mathrm{a}$ & $33.4 \mathrm{c}$ & $44.8 \mathrm{c}$ & $63.3 c$ & $88.2 \mathrm{c}$ & $122.5 \mathrm{c}$ & $167.7 \mathrm{~b}$ & $6384.17 d$ & $208.49 d$ & $19.91 c$ & $418.74 d$ & $43.38 \mathrm{c}$ & $62.91 b$ \\
\hline Boscalid $\left(0.075 \mathrm{~g} \mathrm{~L}^{-1}\right)$ & $26.5 a$ & $37.1 \mathrm{~b}$ & $49.9 b$ & $70.4 \mathrm{~b}$ & $95.4 \mathrm{~b}$ & $140.2 \mathrm{~b}$ & $175.0 \mathrm{a}$ & $8172.24 \mathrm{c}$ & $276.57 c$ & $28.96 \mathrm{~b}$ & $442.58 c$ & $50.79 b$ & $80.59 a$ \\
\hline $\begin{array}{l}\text { Boscalid }\left(0.100 \mathrm{~g} \mathrm{~L}^{-1}\right) \\
\quad+\text { Kresoxim methyl } \\
\left(0.050 \mathrm{~g} \mathrm{~L}^{-1}\right)\end{array}$ & $26.8 \mathrm{a}$ & $37.1 \mathrm{~b}$ & $50.4 \mathrm{~b}$ & $69.9 b$ & $96.2 b$ & $140.8 b$ & $174.9 \mathrm{a}$ & $8019.45 c$ & $271.21 \mathrm{c}$ & $27.40 \mathrm{~b}$ & $438.16 c$ & $47.26 \mathrm{~b}$ & $78.27 \mathrm{a}$ \\
\hline Pyraclostrobin $\left(0.100 \mathrm{~g} \mathrm{~L}^{-1}\right)$ & $27.3 \mathrm{a}$ & $36.8 \mathrm{~b}$ & $50.1 \mathrm{~b}$ & $70.9 b$ & $96.9 b$ & $141.4 \mathrm{~b}$ & $174.2 \mathrm{a}$ & $8121.25 c$ & $274.23 c$ & $28.19 b$ & $441.92 c$ & $49.98 b$ & $79.48 \mathrm{a}$ \\
\hline $\begin{array}{l}\text { Fluxapyroxad }\left(0.058 \mathrm{~g} \mathrm{~L}^{-1}\right) \\
\quad+\text { Pyraclostrobin }(0.116 \mathrm{~g} \\
\left.\mathrm{L}^{-1}\right)\end{array}$ & $27.1 \mathrm{a}$ & $39.9 a$ & $55.2 \mathrm{a}$ & $74.1 \mathrm{a}$ & $107.9 \mathrm{a}$ & $154.1 \mathrm{a}$ & $176.9 \mathrm{a}$ & $10,311.51 \mathrm{a}$ & $329.32 a$ & $34.55 \mathrm{a}$ & $501.12 \mathrm{a}$ & $56.24 a$ & $80.94 a$ \\
\hline $\begin{array}{l}\text { Metiram }\left(1.100 \mathrm{~g} \mathrm{~L}^{-1}\right) \\
\quad+\text { Pyraclostrobin }(0.100 \mathrm{~g} \\
\left.\quad \mathrm{L}^{-1}\right)\end{array}$ & $27.0 \mathrm{a}$ & $39.1 \mathrm{a}$ & $53.9 \mathrm{a}$ & $71.6 \mathrm{ab}$ & $105.8 \mathrm{a}$ & $151.0 \mathrm{a}$ & $176.1 \mathrm{a}$ & $9889.77 b$ & $314.18 b$ & $32.97 a$ & $488.67 b$ & $54.73 a$ & $79.99 a$ \\
\hline CV (\%) & 10.3 & 12.2 & 9.9 & 15.2 & 13.5 & 12.9 & 14.2 & 9.56 & 12.32 & 11.25 & 10.59 & 12.56 & 8.78 \\
\hline
\end{tabular}

Mean $(n=5)$ followed by different letters in the column differ significantly from each other by the Tukey test at $5 \%$ probability $(P \leq 0.05$.

performed using Environment R software (R Development Core Team, 2016).

\section{Results}

\subsection{Development of tomato plants}

Analyzing the initial development of tomato plants submitted to different treatments: inoculated control (Inoc-control), absolute control (Abs-control), boscalid (Bosc), boscalid with kresoxim methyl (Bosc + Kre), pyraclostrobin (Pyra), fluxapyroxad with pyraclostrobin (Flux + Pyra) and metiram with pyraclostrobin (Me + Pyra), significant differences $(\mathrm{P} \leq 0.05)$ were observed among treatments, presenting similar behavior in 2015 and 2016 (Table 1).

At 14 DAT (evaluation performed before the first application of treatments, which occurred at 15 DAT), there was no significant difference among treatments ( $\mathrm{P} \leq 0.05)$. From 21 DAT extending up to 49 DAT, the highest plant height values were observed in Flux + Pyra and Me + Pyra treatments. The height of plants at 56 DAT did not differ significantly among fungicides; however, they were higher than controls, which had the lowest mean height values.

Significant differences $(\mathrm{P} \leq 0.05)$ were observed among treatments for the following variables: leaf area $\left(\mathrm{cm}^{2}\right)$, fresh and dry mass of leaves, stems and roots (Table 1). The highest leaf area values were verified in the Flux + Pyra treatment $\left(10,452.1\right.$ and $10,311.5 \mathrm{~cm}^{2}$ of plant $^{-1}$ leaf area, in years of 2015 and 2016 , respectively) followed by Me + Pyra treatment ( 9914.3 and $9889.8 \mathrm{~cm}^{2}$ of plant ${ }^{-1}$ leaf area, in years 2015 and 2016, respectively). In contrast, the lowest mean leaf area values were identified in Inoc-control treatment (3298.3 and $3098.1 \mathrm{~cm}^{2}$ of plant ${ }^{-1}$ leaf area, in years 2015 and 2016, respectively) and Abs-control (6247.8 and $6384.2 \mathrm{~cm}^{2}$ of plant ${ }^{-1}$ leaf area, in years 2015 and 2016, respectively).

Flux + Pyra followed by Me + Pyra treatments showed the highest accumulations of fresh and dry biomass with significant increases, differing from the other treatments $(P \leq 0.05)$. However, there was no significant difference among fungicides for the fresh and dry mass accumulation of roots, differing only from controls. 
Inoculated control (inoculum + water) एत/ Absolute control (water) $\square$ Boscalid $\left(0.075 \mathrm{~g} \mathrm{~L}^{-1}\right) \mathrm{MI}$ Boscalid $\left(0.100 \mathrm{~g} \mathrm{~L}^{-1}\right)+\operatorname{Kresoxim}$ methyl $(0.050 \mathrm{~g} \mathrm{~L}$ ) $\square$ Pyraclostrobin $\left(0.100 \mathrm{gL}^{-1}\right) \circledast$ Fluxapyroxad $\left(0.058 \mathrm{~g} \mathrm{~L}^{-1}\right)+$ Pyraclostrobin $\left(0.116 \mathrm{~g} \mathrm{~L}^{-1}\right) \square$ Metiram $\left(1.100 \mathrm{gL}^{-1}\right)+$ Pyraclostrobin $\left(0.100 \mathrm{gL}^{-1}\right)$
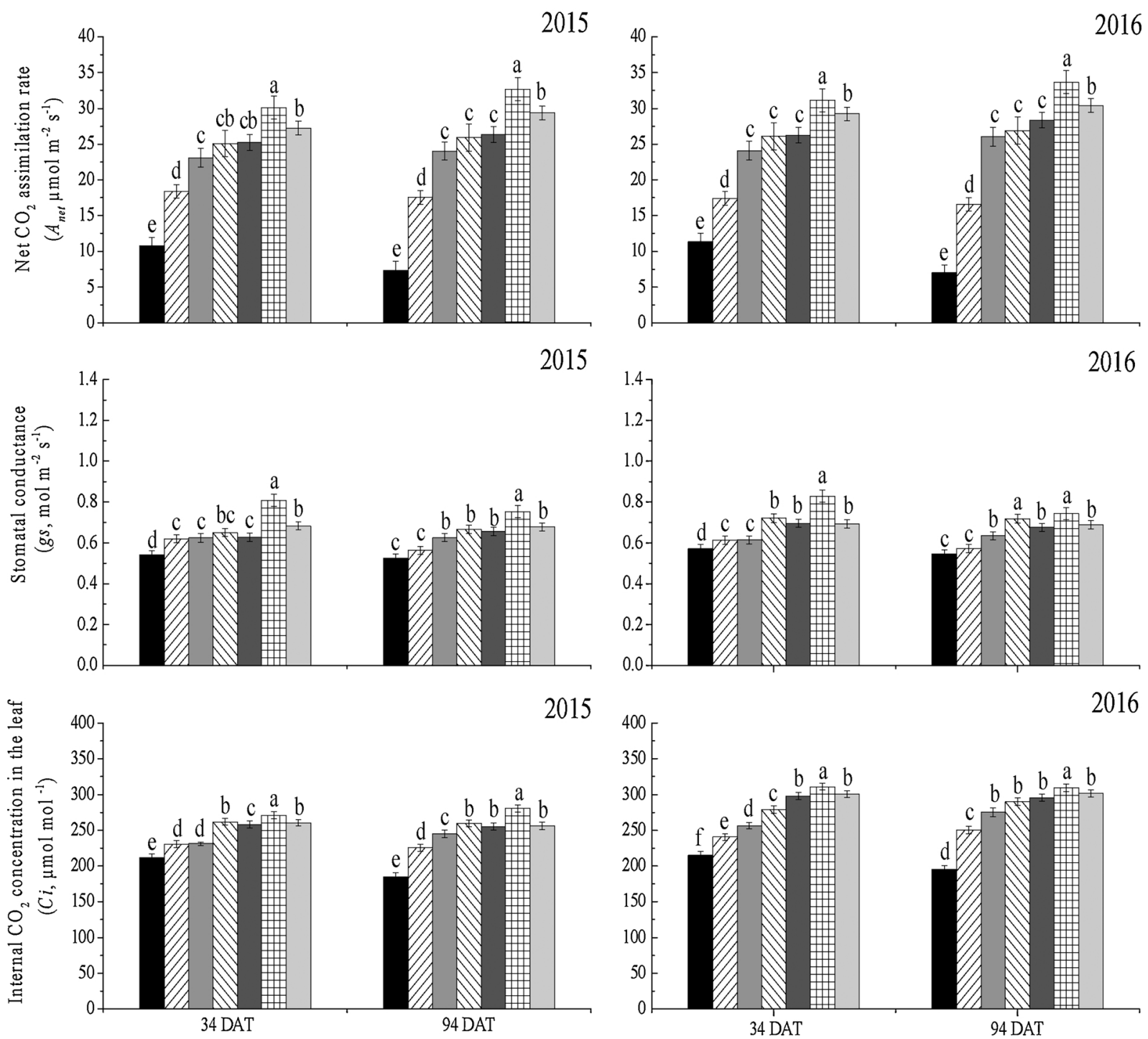

Fig. 1. Net $\mathrm{CO}_{2}$ assimilation rate $\left(A_{\text {net }}, \mu \mathrm{mol} \mathrm{m} \mathrm{m}^{-2} \mathrm{~s}^{-1}\right)$, stomatal conductance $\left(g_{s}, \mathrm{~mol} \mathrm{~m}^{-2} \mathrm{~s}^{-1}\right)$ and internal $\mathrm{CO}_{2}$ concentration in the leaf $\left(\mathrm{Ci}\right.$, $\mu \mathrm{mol}$ mol$\left.{ }^{-1}\right)$ of hybrid tomato plants Conquistador cv. cultivated in greenhouse, treated with different fungicides with physiological effects and inoculated with Alternaria solani, at 34 and 94 days after transplanting (DAT), in years 2015 and 2016. Means $(n=5)$ followed by different letters, in the same evaluation, differ by the Tukey test at $5 \%$ probability level $(\mathrm{P} \leq 0.05)$. Bars indicate standard deviation of the mean.

\subsection{Photosynthetic efficiency}

In gas exchange evaluations performed at 34 and 94 DAT (Figs. 1 and 2), significant differences $(\mathrm{P} \leq 0.05)$ were observed among treatments, in the two years evaluated, presenting similar behavior. Plants treated with Flux + Pyra obtained the highest $\mathrm{CO}_{2}$ assimilation rates $\left(A, \mu \mathrm{mol} \mathrm{m}{ }^{-2} \mathrm{~s}^{-1}\right)$, stomatal conductance $\left(g_{s}, \mathrm{~mol} \mathrm{~m}^{-2} \mathrm{~s}^{-1}\right)$ and internal $\mathrm{CO}_{2}$ concentration on leaf $\left(\mathrm{Ci}, \mu \mathrm{mol} \mathrm{mol}{ }^{-1}\right)$ (Fig. 1), statistically differing from the other treatments $(\mathrm{P} \leq 0.05)$.

For the transpiration rate $\left(E, \mathrm{mmol} \mathrm{m}^{-2} \mathrm{~s}^{-1}\right)$ of plants at 34 and 94 DAT, it was observed that there was no statistical difference among fungicides tested for this characteristic (Fig. 2).

However, the transpiration of plants in these treatments is smaller when compared to controls, significantly differing from them $(\mathrm{P} \leq 0.05)$. Evaluating water use efficiency (WUE, $A_{\text {net }} / E, \mu \mathrm{mol} \mathrm{CO}_{2}$ mmol $\mathrm{H}_{2} \mathrm{O}^{-1}$ ) and carboxylation efficiency $\left(A_{\text {net }} / \mathrm{Ci}\right.$ ) (Fig. 2), Flux + Pyra treatment again stands out and statistically differs $(\mathrm{P} \leq 0.05)$ from the other treatments, at 34 and 94 DAT.

Plants treated with Flux + Pyra showed higher WUE $\left(A_{\text {net }} / E\right)$ at 34 DAT (3.99 and $4.13 \mu \mathrm{mol} \mathrm{CO} \mathrm{CO}_{2} \mathrm{mmol}_{2} \mathrm{O}^{-1}$ in 2015 and 2016, respectively) and at 94 DAT (4.10 and $4.22 \mu \mathrm{mol} \mathrm{CO}_{2} \mathrm{mmol} \mathrm{H}_{2} \mathrm{O}^{-1}$ in 2015 and 2016, respectively). In contrast, Inoc-control plants had the lowest WUE $\left(A_{\text {net }} E\right)$. between 0.70 and $1.14 \mu \mathrm{mol} \mathrm{CO} \mathrm{Cm}_{2} \mathrm{mmol}_{2} \mathrm{O}^{-1}$, in the two-year experiment. Abs-control plants also presented lower values for the evaluated gas exchanges characteristics when compared to the different fungicides tested, but superior to Inoc-control.

Fungicide application also showed significant effects $(P \leq 0.05)$ on the chlorophyll fluorescence parameters evaluated at 34 and 94 DAT. Variables fluorescence $\left(F_{v}\right)$, maximum efficiency of PSII $\left(F_{v} / F_{m}\right)$, photochemical quantum yield of PSII, Y(II) and relative electron transfer rate (ETR) showed similar behavior in the two years evaluated (Fig. 3).

The $F_{v} / F_{m}$ values were significantly different $(\mathrm{P} \leq 0.05)$ among treatments, but there was no statistical difference for plants treated with the different fungicides, which had higher quantum yield values of 


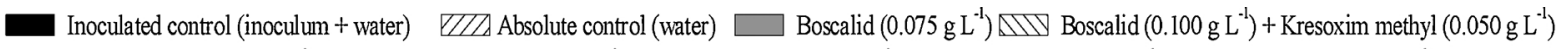

$\square$ Pyraclostrobin $\left(0.100 \mathrm{~g} \mathrm{~L}^{-1}\right)$ \#冊 Fluxapyroxad $\left(0.058 \mathrm{~g} \mathrm{~L}^{-1}\right)+$ Pyraclostrobin $\left(0.116 \mathrm{gL}^{-1}\right) \square$ Metiram $\left(1.100 \mathrm{~g} \mathrm{~L}^{-1}\right)+$ Pyraclostrobin $\left(0.100 \mathrm{gL}^{-1}\right)$
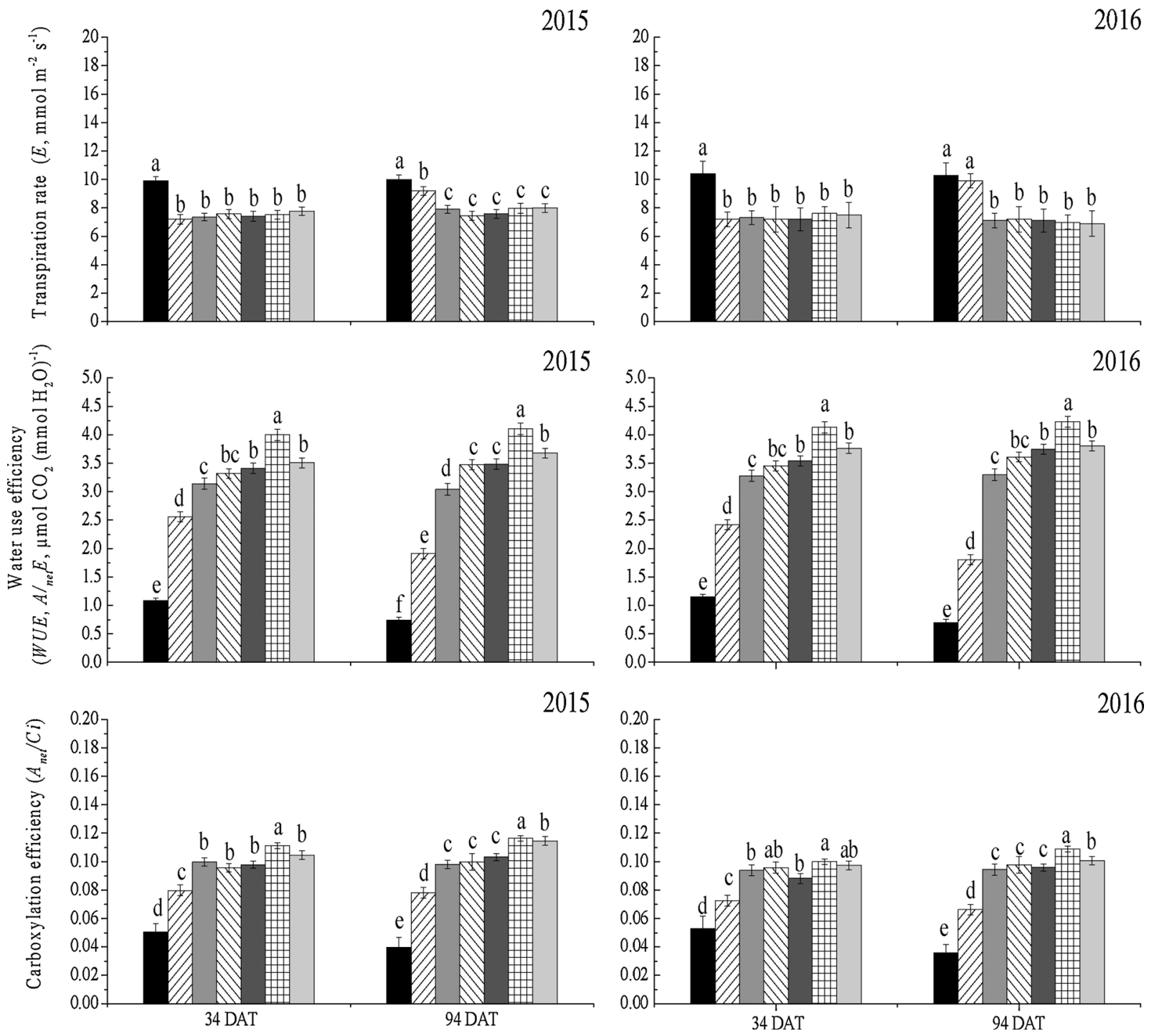

Fig. 2. Transpiration rate $\left(E, \mathrm{mmol} \mathrm{m}{ }^{-2} \mathrm{~s}^{-1}\right)$, water use efficiency (WUE, $\left.A_{\text {net }} / E, \mu \mathrm{mol} \mathrm{CO}_{2}\left(\mathrm{mmol} \mathrm{H}_{2} \mathrm{O}\right)^{-1}\right)$ and carboxylation efficiency $\left(A_{\text {net }} / C i\right)$ of hybrid tomato plants Conquistador cv. cultivated in greenhouse, treated with different fungicides with physiological effects and inoculated with Alternaria solani, at 34 and 94 days after transplanting (DAT), in years 2015 and 2016 . Means $(n=5)$ followed by different letters, in the same evaluation, differ by the Tukey test at $5 \%$ probability level $(\mathrm{P} \leq 0.05)$. Bars indicate standard deviation of the mean.

PSII, Y (II) at 34 and 94 DAT, with values varying between 0.79 and 0.86 .

In Inoc-control plants, lower $F_{v} / F_{m}$ values were observed at 34 and 94 DAT, with a decrease from 0.64 to 0.43 , showing a marked decline from one evaluation to another, possibly indicating the presence of damages in the photosynthetic apparatus. In the Abs-control treatment, the $F_{v} / F_{m}$ values at 34 and 94 DAT were 0.73 and 0.62 , respectively. In relation to the $F_{v}$ parameters and effective quantum yield of PSII, Y(II), a significant difference was observed among treatments (Fig. 3), with Flux + Pyra treatment showing the highest $F_{v}$ values at 94 DAT, however, without differing from the other fungicides at 34 DAT.

The ETR results (Fig. 3) were significantly different among treatments $(P \leq 0.05)$, being higher in treatments with different fungicides (Flux + Pyra $>$ Me + Pyra $>$ Pyra $>$ Bosc + Kre $>$ Bosc $)$. For all evaluated parameters, the lowest values were observed in Inoc-control plants, followed by Abs-control.

\subsection{Photosynthetic pigments and activity of the nitrate reductase enzyme}

The content of photosynthetic pigments in leaves analyzed at 15, 20, 35, 50, 65, 80, 95 and 110 DAT (Fig. 4) showed a significant difference $(P \leq 0.05)$ among treatments in the two years evaluated.

In the first evaluation (15 DAT), before the application of fungicides, there was no significant statistical difference $(P \leq 0.05)$ among treatments, however, from the 20 DAT, plants treated with Flux + Pyra presented the highest chlorophyll $a$ and $b$ levels ( $\mu \mathrm{g} g$ fresh matter ${ }^{-1}$ ), with an expressive increase with the advancement of evaluations. This behavior is related to the sum of the effects of applications, since evaluations between 20 and 95 DAT were always carried out on the 5th day after application, so at 20, 35, 50, 65, 80 and 95 DAT we have: 5th day after $1 \mathrm{st}, 2 \mathrm{nd}, 3 \mathrm{rd}, 4 \mathrm{th}$, 5th and 6th treatments, respectively.

It was also observed that with the advancement of evaluations, Me + Pyra treatment showed similar effect to Flux + Pyra, not statistically differing in chlorophyll $a$ and $b$, in some evaluations. Again, the lowest photosynthetic pigment contents were observed in Inoc-control 
Inoculated control (inoculum + water) $\square] \triangle$ Absolute control (water) $\square$ Boscalid $\left(0.075 \mathrm{~g} \mathrm{~L}^{-1}\right) \square$ Boscalid $\left(0.100 \mathrm{~g} \mathrm{~L}^{-1}\right)+$ Kresoxim methyl $\left(0.050 \mathrm{~g} \mathrm{~L}^{-1}\right)$ Pyraclostrobin $\left(0.100 \mathrm{~g} \mathrm{~L}^{-1}\right)$ 巴冊 Fluxapyroxad $\left(0.058 \mathrm{gL}^{-1}\right)+$ Pyraclostrobin $\left(0.116 \mathrm{gL}^{-1}\right) \square$ Metiram $\left(1.100 \mathrm{~g} \mathrm{~L}^{-1}\right)+$ Pyraclostrobin $\left(0.100 \mathrm{gL}^{-1}\right)$
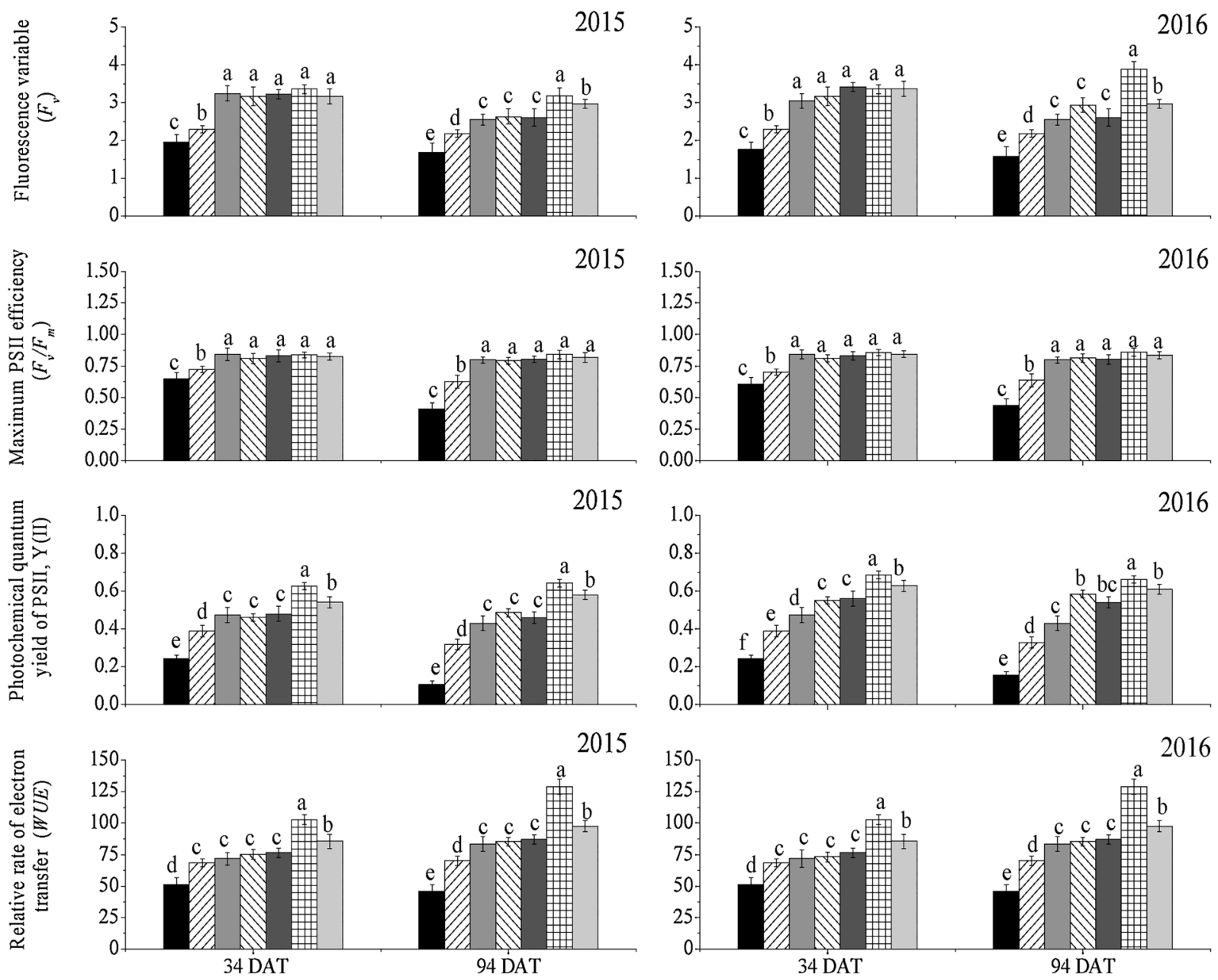

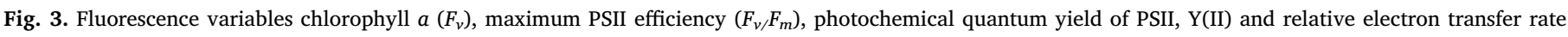

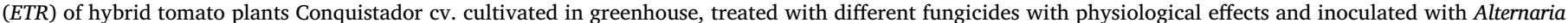

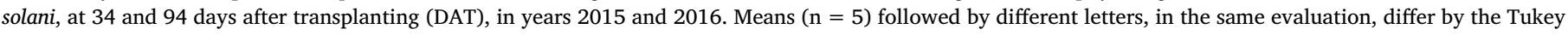
test at $5 \%$ probability level $(\mathrm{P} \leq 0.05)$. Bars indicate standard deviation of the mean.

treatments, followed by Abs-control, in all evaluations performed at 15 DAT.

Regarding the carotenoid contents, higher values were observed for plants treated with Flux + Pyra, followed by Me + Pyra, significantly differing $(P \leq 0.05)$ from each other and from other treatments in evaluations performed from 20 to 110 DAT in the two years evaluated.

According to Fig. 5, the physiological effects on the activity of the nitrate reductase enzyme at 15, 20,35, 50, 65, 80, 95 and 110 DAT were evaluated (same days in which the content of photosynthetic pigments were evaluated). In general, plants treated with the different fungicides showed higher activity of the nitrate reductase enzyme throughout the evaluations, with a significant difference $(P \leq 0.05)$ among treatments, in both evaluated years. Plants that received application of Flux + Pyra and Me + Pyra were those that presented greater activity of the nitrate reductase enzyme (NR) in all collections.

However, two peaks of NR enzyme activity occurred in these treatments, the first at 50,65 and 80 DAT and the second peak at 95 and 110 DAT. In contrast, the lower levels of these pigments and NR enzyme activity were observed for Inoc-control plants, followed by Abscontrol treatment in all evaluations.

\subsection{Carbohydrate synthesis and translocation}

Since carbohydrate production is the product of photosynthesis, relationships between source-drain organs are also influenced by photosynthetic efficiency. In this way, the translocation of photoassimilates in tomato plants at 50 and 120 DAT (Table 2) was evaluated and it was observed that the total sugar contents in leaves, stem and fruits, both at 50 and 120 DAT, in all plants analyzed, was in the following order: fruits $>$ stem $>$ leaves.

However, there was a significant difference $(\mathrm{P} \leq 0.05)$ in the concentration of total sugars among different organs, which was also observed for the content of reducing sugars. However, Flux + Pyra and $\mathrm{Me}+$ Pyra treatments presented the highest concentrations of these carbohydrates in leaves, stems and fruits, in both evaluations (50 and 120 DAT), significantly differing $(\mathrm{P} \leq 0.05)$ from the other treatments, with similar behavior in both evaluated years.

Verifying carbohydrate levels in Bosc, Bosc + Kre and Pyra treatments at 50 and 120 DAT, it was observed that there was no statistical difference between them for the content of total and reducing sugars in the evaluated organs. However, these three treatments significantly differed from the others, presenting mean values of these characteristics higher than those of controls (Inoc-control and Abs-control) and lower 
- Inoculated control (inoculum + water) $\quad$ * Absolute control (water) - Boscalid $\left(0.075 \mathrm{gL}^{-1}\right)-\diamond-\operatorname{Boscalid}\left(0.100 \mathrm{gL}^{-1}\right)+\operatorname{Kresoxim}$ methyl $\left(0.050 \mathrm{gL}^{-1}\right)$

- Pyraclostrobin $\left(0.100 \mathrm{gL}^{-1}\right)-$ - Fluxapyroxad $\left(0.058 \mathrm{gL}^{-1}\right)+$ Pyraclostrobin $\left(0.116 \mathrm{gL}^{-1}\right)-\mathrm{O}-$ Metiram $\left(1.100 \mathrm{gL}^{-1}\right)+$ Pyraclostrobin $\left(0.100 \mathrm{~g} \mathrm{~L}^{-1}\right)$
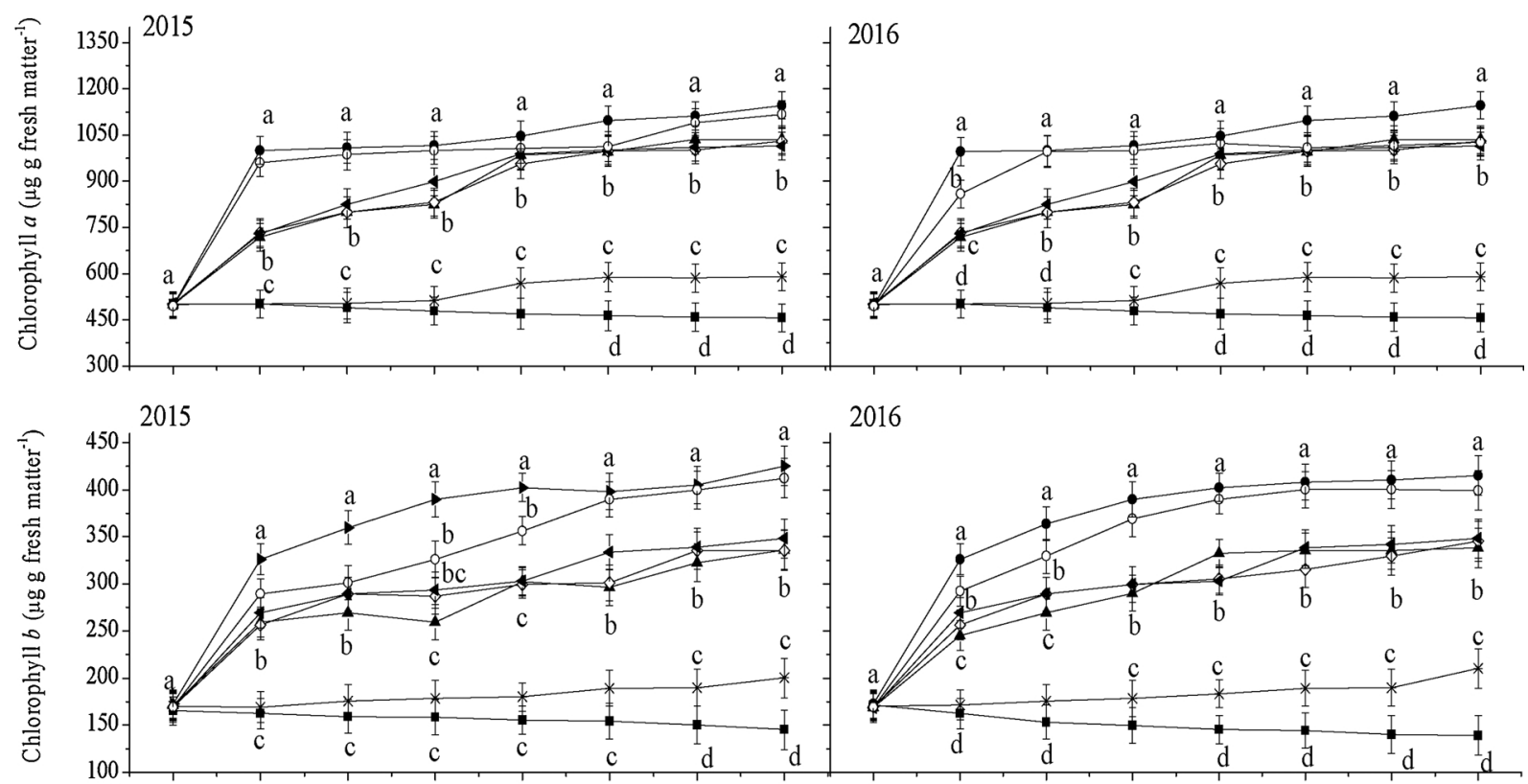

2016

2015
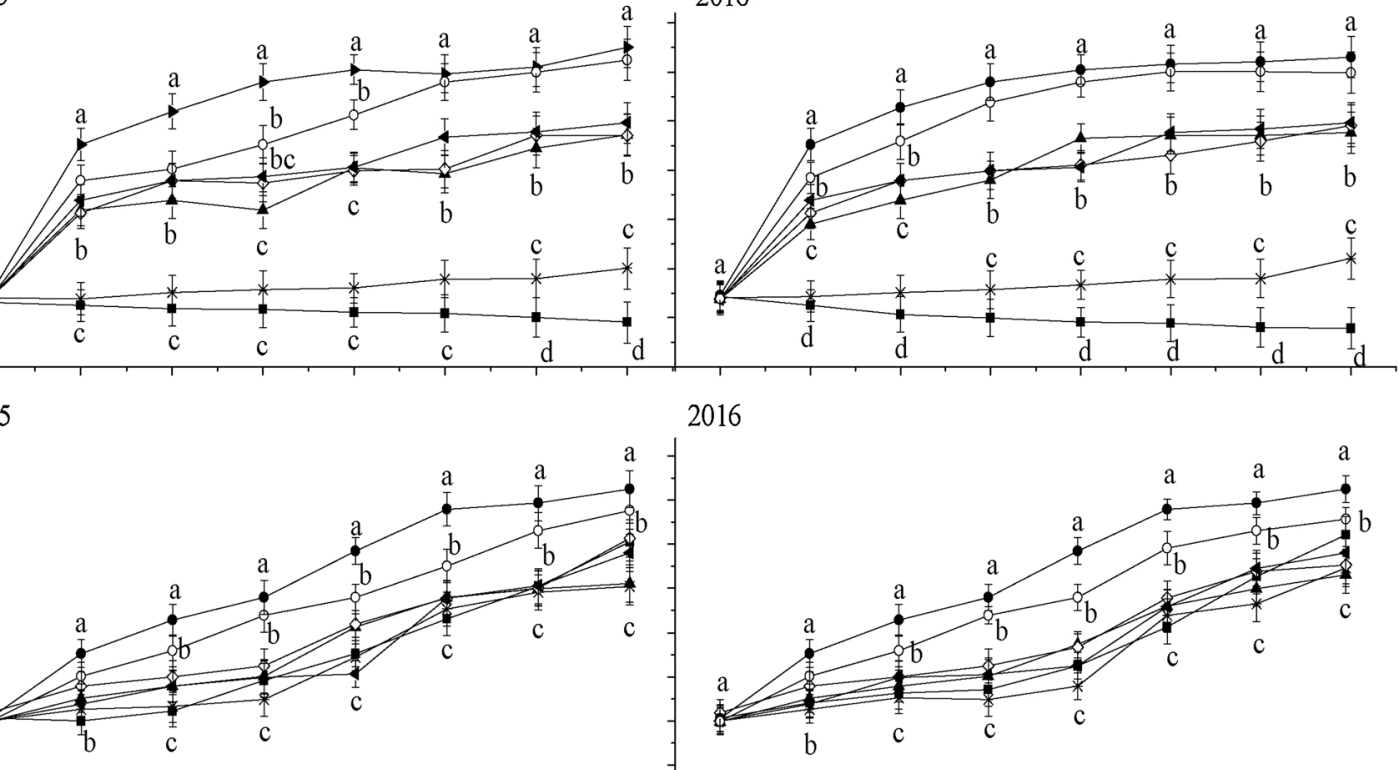

2016

Fig. 4. Chlorophyll $a$ ( $\mu \mathrm{g} g$ fresh matter ${ }^{-1}$ ), chlorophyll $b$ ( $\mu \mathrm{g} g$ fresh matter $^{-1}$ ) and carotenoids ( $\mu \mathrm{g} \mathrm{g}$ fresh matter ${ }^{-1}$ ) in hybrid tomato plants Conquistador cv. cultivated in greenhouse, treated with different fungicides of physiological effects and inoculated with Alternaria solani at 15, 20, 35, 50, 65, 80, 95 and 110 days after transplanting (DAT) in years 2015 and 2016. Means $(\mathrm{n}=5)$ followed by distinct letters in the same evaluation differ by the Tukey test at $5 \%$ probability level $(\mathrm{P} \leq 0.05)$. Bars indicate standard deviation of the mean.

than those observed for Flux + Pyra and Me + Pyra, both at 50 DAT and at 120 DAT.

As for the concentration of reducing sugars, it was observed that the lowest values were found in the leaves of plants treated with Flux + Pyra and Me + yira, significantly differing $(P \leq 0.05)$ from the other treatments.

The main drain in tomato plants from flowering are fruits, as observed for Flux + Pyra and Me + Pyra treatments, which presented the highest concentrations of total and reducing sugars at $120 \mathrm{DAT}$, significantly differing $(\mathrm{P} \leq 0.05)$ from the other treatments.

\subsection{Control of Alternaria solani}

To verify the effect on $A$. solani control, the area under the progression curve of the disease (AUPCD) (Fig. 6) was evaluated in the two years analyzed and it was observed that there was a reduction of the AUPCD for the different fungicides evaluated in relation to the Inoccontrol. It can be observed that the Flux + Pyra, Me + Pyra, Bosc, Pyra and Bosc + Kre fungicides reduced the values in 92.88, 89.54, 56.38, 65.16 and $68.20 \%$ for AUPCD in the year of 2015, and 90.23, 85.68, $48.84,59.09$ and $63.15 \%$ in the year 2016 , respectively, in relation to the inoculated control.
However, the Flux + Pyra and Me + Pyra treatments had the lowest AUPCDs, differing significantly $(\mathrm{p}<0.01$ ) from the other treatments, with similar results in the two years evaluated. The fungicides Bosc, Bosc + Kre and Pyra were also efficient in reducing the severity of the disease, when compared to the Inoc-control.

The Abs-control treatment plants, which were not inoculated at the beginning of the experiment, also showed a certain percentage of disease severity in the last evaluations, so they presented AACPD indices of 248 and 329 in the years of 2015 and 2016, respectively. Due to the ideal conditions observed for the development of the disease, high temperatures and relative humidity (data not shown), in addition to the presence of inoculum (diseased plants: Inoc-control).

\subsection{Production}

According to data in Table 3, it can be observed that there was a significant difference $(\mathrm{P} \leq 0.05)$ among treatments in the production characteristics and fruit yield. The results were similar for both experiments (years 2015 and 2016).

In general, it was observed that the application of fungicides positively influenced the total fruit production $\left(\mathrm{kg} \mathrm{m}^{-2}\right)$, with an increase of $104.2,98.5,63.4,64.7$ and $56.2 \%$ in relation to Inoc-control, for 


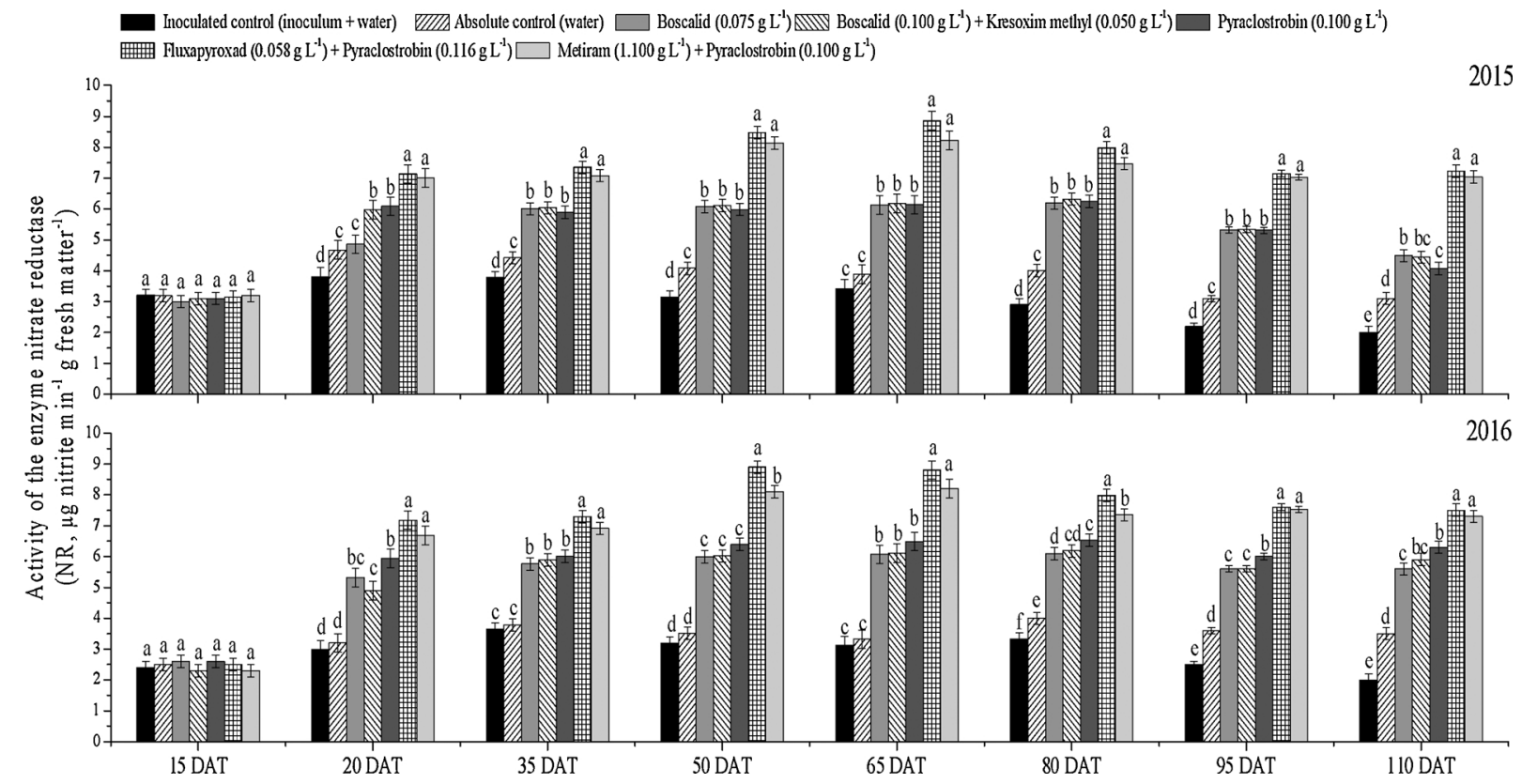

Fig. 5. Activity of the nitrate reductase enzyme (NR, $\mu \mathrm{g}$ nitrite $\min ^{-1} \mathrm{~g}$ fresh matter ${ }^{-1}$ ) in hybrid tomato plants Conquistador cv. cultivated in greenhouse, treated with different fungicides with physiological effects and inoculated with Alternaria solani at 15, 20,35, 50, 65, 80, 95 and 110 days after transplanting (DAT), in years 2015 and 2016. Means $(n=5)$ followed by different letters, in the same evaluation, differ by the Tukey test at $5 \%$ probability level $(P \leq 0.05)$. Bars indicate standard deviation of the mean.

Flux + Pyra, Me + Pyra, Pyra, Bosc + Kre and Bosc, respectively, in year 2015 and 124.8, 115.4, 75.6, 73.3 and $72.0 \%$ in year 2016.

An increase of 76.4, 71.5, 41.2, 42.3 and $35.0 \%$ was also observed in relation to Abs-control for Flux + Pyra, Me + Pyra, Pyra, Bosc + Kre and Bosc treatments, respectively, in year 2015 and 92.6, 84.5, 50.5, 48.5 and $47.4 \%$ in year 2016. The largest increases in production observed in 2016, compared to 2015 , are due to the fact that controls presented lower production in 2016, due to the greater severity of the disease (data not shown).

Treatment with the highest fruit yield was Flux + Pyra (12.2 and $11.7 \mathrm{~kg} \mathrm{~m}^{-2}$ in 2015 and 2016, respectively) followed by Me + Pyra treatment (11.9 and $11.27 \mathrm{~kg} \mathrm{~m}^{-2}$ in 2015 and 2016, respectively), not significantly differing from each other. These treatments also presented the highest number of total fruits $\mathrm{m}^{-2}$, with higher fresh fruit mass $(\mathrm{g}$ fruit $^{-1}$ ) and, consequently, lower percentage of non-commercial fruits.

\section{Discussion}

All plants at the beginning of development (at 14 DAT) had the same developmental pattern, however, during treatment applications, it was generally observed that plants treated with strobilurin and carboxamides presented greater initial development and biomass accumulation when compared to controls. Several studies have reported the physiological effects of these substances on maize (Lima et al., 2009), soybean (Tsumanuma et al., 2010), common bean (Jadoski et al., 2015), carrot (Colombari et al., 2015), sunflower (Tsialtas et al., 2017) and Japanese cucumber (Amaro et al., 2018), where positive effects on biomass accumulation and productivity were observed. In Arabidopsis thaliana Van Dingenen et al. (2017) observed that the application of strobilurins promoted greater plant growth, confirming the positive effects of these substances.

The magnitude of the effects was different for each of the five fungicides tested, with Flux + Pyra treatment, followed by Me + Pyra being those that provided greater leaf development, allowing these plants greater photosynthetic capacity (Kluge et al., 2014). In addition to better development and productivity gains, since $90 \%$ of the dry mass of the plant is formed by photoassimilates that have been converted into biomass (Popov et al., 2003).
Different results were observed in Inoc-control and Abs-control plants, since development evaluations were performed at 120 DAT (after the last fruit harvest), at the end of the crop cycle, Test-Inoc plants were more severely affected (A. solani inoculated at 16 DAT). Due to its high aggressiveness, the incidence of $A$. solani reduces plant vigor and development, as it causes damage to the photosynthetically active area and defoliation in more advanced stages of the disease (Töfoli et al., 2014).

This explains, in part, the smaller leaf area observed in Inoc-control plants, because Abs-control plants, which were not inoculated at the beginning of experiments, also presented lower leaf development, being significantly different from the other treatments. These results indicate that these fungicides, in addition to controlling the disease efficiently, promote a positive effect on leaf expansion, as also observed by Fagan et al. (2010) in soybean.

All fungicides applied increased the photosynthetic efficiency at 34 and 94 DAT in relation to controls, however, Flux + Pyra presented the best effects on photosynthetic efficiency in tomato plants. The results of other studies demonstrate an increase in the $\mathrm{CO}_{2}$ assimilation rate and elevation in the net photosynthetic rate after application of strobilurins, such as pyraclostrobin and kresoxim-methyl, and carboxamides, such as boscalid, in tomato plants (Ramos et al., 2015), Japanese cucumber (Amaro et al., 2018) and soybean (Fagan et al.,2010).

The photosynthetic parameters of wheat plants were higher with the application of strobilurins (Nason et al., 2007) however, these authors observed greater stomatal conductance together with higher transpiration rate, unlike results observed in tomato plants. Plants treated with Flux + Pyra presented lower $E$ value and, consequently, higher WUE $\left(A_{\text {net }} / E\right)$ in both evaluations, indicating greater capacity to assimilate $\mathrm{CO}_{2}$ with low water loss, generating greater water savings and higher synthesis of photoassimilates.

Similar effects were observed in tomato plants with application of pyraclostrobin plus boscalid (Ramos et al., 2015) and azoxystrobin (Giuliani et al., 2010). In beans, the application of pyraclostrobin improved the maintenance of $g_{s}$ in plants under water stress, which is advantageous (Jadoski et al., 2015). These authors point out that the maintenance of $g_{s}$ in the increase of water tension depends on the dynamic balance among the three carboxylation factors: $A_{\text {net }} / C_{i}, E$ and 
Table 2

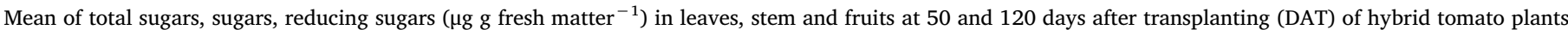

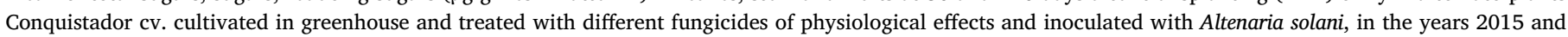
2016.

\begin{tabular}{|c|c|c|c|c|c|c|c|c|c|c|c|c|}
\hline \multirow[t]{3}{*}{ Treatments } & \multicolumn{6}{|c|}{ Concentration of carbohydrates - 50 DAT } & \multicolumn{6}{|c|}{ Concentration of carbohydrates - 120 DAT } \\
\hline & \multicolumn{3}{|c|}{$\begin{array}{l}\text { Total Sugars } \\
\left(\mu g \mathrm{~g} \text { fresh matter }{ }^{-1}\right)\end{array}$} & \multicolumn{3}{|c|}{$\begin{array}{l}\text { Reducing sugars } \\
\left(\mu g \text { g fresh } \text { matter }^{-1}\right)\end{array}$} & \multicolumn{3}{|c|}{$\begin{array}{l}\text { Total Sugars } \\
\left(\mu \mathrm{g} g \text { fresh matter }{ }^{-1}\right)\end{array}$} & \multicolumn{3}{|c|}{$\begin{array}{l}\text { Reducing sugars } \\
\left(\mu \mathrm{g} g \text { fresh matter }{ }^{-1}\right)\end{array}$} \\
\hline & Leaves & Stem & Fruits & Leaves & Stem & Fruits & Leaves & Stem & Fruits & Leaves & Stem & Fruits \\
\hline $\begin{array}{l}\text { Inoculated control } \\
\quad \text { (inoculum + water) }\end{array}$ & $85.2 \mathrm{cC}$ & $110.6 \mathrm{cB}$ & $298.3 \mathrm{cA}$ & $48.6 \mathrm{aC}$ & $78.9 \mathrm{aB}$ & $65.9 \mathrm{cA}$ & $63.2 \mathrm{cC}$ & $102.3 \mathrm{cB}$ & $302.4 \mathrm{cA}$ & $28.4 \mathrm{aC}$ & $50.2 \mathrm{cB}$ & $72.6 \mathrm{cA}$ \\
\hline Absolute control (water) & $82.1 \mathrm{cC}$ & $113.2 \mathrm{cB}$ & 299.3cA & $50.2 \mathrm{aC}$ & $81.8 \mathrm{aB}$ & $67.2 \mathrm{cA}$ & $60.7 \mathrm{cC}$ & $99.8 \mathrm{cB}$ & $307.2 \mathrm{cA}$ & $29.6 \mathrm{aC}$ & $52.6 \mathrm{cB}$ & $74.9 \mathrm{cA}$ \\
\hline Boscalid $\left(0.075 \mathrm{~g} \mathrm{~L}^{-1}\right)$ & $92.4 \mathrm{bC}$ & $136.7 \mathrm{bB}$ & $336.5 \mathrm{bA}$ & $39.3 \mathrm{bC}$ & $61.9 \mathrm{bB}$ & $105.6 \mathrm{bA}$ & $80.8 \mathrm{bC}$ & $126.6 \mathrm{bB}$ & 382.1bA & $21.2 \mathrm{bC}$ & $42.7 \mathrm{bB}$ & $125.6 \mathrm{bA}$ \\
\hline $\begin{array}{l}\text { Boscalid }\left(0.100 \mathrm{~g} \mathrm{~L}^{-1}\right) \\
\quad+\text { Kresoxim methyl }\left(0.050 \mathrm{~g} \mathrm{~L}^{-1}\right)\end{array}$ & $94.9 \mathrm{bC}$ & $134.6 \mathrm{bB}$ & $325.8 \mathrm{bA}$ & $40.2 \mathrm{bC}$ & $63.5 \mathrm{bB}$ & $102.8 \mathrm{bA}$ & $80.2 \mathrm{bC}$ & $131.6 \mathrm{bB}$ & $376.9 \mathrm{bA}$ & $20.1 \mathrm{bC}$ & $43.5 \mathrm{bB}$ & $118.3 \mathrm{bA}$ \\
\hline Pyraclostrobin $\left(0.100 \mathrm{~g} \mathrm{~L}^{-1}\right)$ & $95.6 \mathrm{bC}$ & $138.5 \mathrm{bB}$ & $330.5 \mathrm{bA}$ & $39.8 \mathrm{bC}$ & $60.5 \mathrm{bB}$ & 99.3bA & $79.3 b C$ & $130.6 \mathrm{bB}$ & 399.7bA & $21.8 \mathrm{bC}$ & $39.8 \mathrm{bB}$ & $120.7 \mathrm{bA}$ \\
\hline $\begin{array}{l}\text { Fluxapyroxad }\left(0.058 \mathrm{~g} \mathrm{~L}^{-1}\right) \\
\quad+\text { Pyraclostrobin }\left(0.116 \mathrm{~g} \mathrm{~L}^{-1}\right)\end{array}$ & $126.4 \mathrm{aC}$ & $154.6 \mathrm{aB}$ & $385.9 \mathrm{aA}$ & $28.1 \mathrm{cC}$ & $49.6 \mathrm{cB}$ & $123.5 \mathrm{aA}$ & $99.6 \mathrm{aC}$ & $152.3 \mathrm{aB}$ & $435.6 \mathrm{aA}$ & $13.3 \mathrm{cC}$ & $22.3 \mathrm{aB}$ & $166.0 \mathrm{aA}$ \\
\hline $\begin{array}{l}\text { Metiram }\left(1.100 \mathrm{~g} \mathrm{~L}^{-1}\right) \\
\quad+\text { Pyraclostrobin }\left(0.100 \mathrm{~g} \mathrm{~L}^{-1}\right)\end{array}$ & $124.1 \mathrm{aC}$ & $149.7 \mathrm{aB}$ & $372.1 \mathrm{aA}$ & $27.7 \mathrm{cC}$ & $52.9 \mathrm{cB}$ & $120.9 \mathrm{aA}$ & $98.4 \mathrm{aC}$ & $150.6 \mathrm{aB}$ & $429.7 \mathrm{aA}$ & $15.6 c \mathrm{C}$ & $22.7 \mathrm{aB}$ & $162.2 \mathrm{aA}$ \\
\hline $\mathrm{CV}(\%)$ & 8.6 & 9.2 & 7.8 & 5.9 & 8.7 & 8.5 & 10.7 & 9.3 & 9.2 & 8.7 & 9.1 & 7.6 \\
\hline
\end{tabular}

\begin{tabular}{|c|c|c|c|c|c|c|c|c|c|c|c|c|}
\hline \multirow[t]{3}{*}{ Treatments } & \multicolumn{6}{|c|}{ Concentration of carbohydrates - 50 DAT } & \multicolumn{6}{|c|}{ Concentration of carbohydrates - 120 DAT } \\
\hline & Total Sugars & $\begin{array}{l}(\mu \mathrm{g} g \text { fresh } \\
\left.\text { matter }^{-1}\right)\end{array}$ & & $\begin{array}{l}\text { Reducing } \\
\text { sugars }\end{array}$ & $\begin{array}{l}(\mu \mathrm{g} g \text { fresh } \\
\left.\text { matter }^{-1}\right)\end{array}$ & & $\begin{array}{l}\text { Total } \\
\text { Sugars }\end{array}$ & $\begin{array}{l}\text { ( } \mu \mathrm{g} g \text { fresh } \\
\text { matter }^{-1} \text { ) }\end{array}$ & & $\begin{array}{l}\text { Reducing } \\
\text { sugars }\end{array}$ & $\begin{array}{l}(\mu \mathrm{g} g \text { fresh } \\
\left.\text { matter }^{-1}\right)\end{array}$ & \\
\hline & Leaves & Stem & Fruits & Leaves & Stem & Fruits & Leaves & Stem & Fruits & Leaves & Stem & Fruits \\
\hline $\begin{array}{l}\text { Inoculated control } \\
\qquad \text { (inoculum + water) }\end{array}$ & $89.5 \mathrm{cC}$ & $121.9 \mathrm{cB}$ & 299.9cA & $45.5 \mathrm{aC}$ & $84.6 \mathrm{aB}$ & $60.3 \mathrm{cA}$ & $68.0 \mathrm{cC}$ & $99.3 \mathrm{cB}$ & $322.9 \mathrm{cA}$ & $31.9 \mathrm{aC}$ & $56.2 \mathrm{cB}$ & $78.1 \mathrm{cA}$ \\
\hline Absolute control (water) & $86.3 \mathrm{cC}$ & $124.2 \mathrm{cB}$ & 303.1cA & $48.2 \mathrm{aC}$ & 85.7aB & $62.4 \mathrm{cA}$ & $66.8 \mathrm{cC}$ & $103.6 \mathrm{cB}$ & $318.9 \mathrm{cA}$ & $32.6 \mathrm{aC}$ & $55.0 \mathrm{cB}$ & $79.4 \mathrm{cA}$ \\
\hline Boscalid $\left(0.075 \mathrm{~g} \mathrm{~L}^{-1}\right)$ & $96.2 b C$ & 143.1bB & $342.5 \mathrm{bA}$ & $37.3 \mathrm{bC}$ & $66.2 \mathrm{bB}$ & 95.3bA & $80.2 b C$ & 126.6bB & $384.1 \mathrm{bA}$ & $25.1 \mathrm{bC}$ & $40.7 \mathrm{bB}$ & $123.7 \mathrm{bA}$ \\
\hline $\begin{array}{l}\text { Boscalid }\left(0.100 \mathrm{~g} \mathrm{~L}^{-1}\right) \\
\quad+\text { Kresoxim methyl } \\
\left(0.050 \mathrm{~g} \mathrm{~L}^{-1}\right)\end{array}$ & $98.8 \mathrm{bC}$ & $147.8 \mathrm{bB}$ & $338.3 \mathrm{bA}$ & $36.4 \mathrm{bC}$ & $65.6 \mathrm{bB}$ & $96.8 \mathrm{bA}$ & $78.4 \mathrm{bC}$ & $123.2 \mathrm{bB}$ & $385.9 \mathrm{bA}$ & $23.9 \mathrm{bC}$ & $44.6 \mathrm{bB}$ & $126.9 \mathrm{bA}$ \\
\hline $\begin{array}{l}\text { Pyraclostrobin }(0.100 \mathrm{~g} \\
\left.\mathrm{L}^{-1}\right)\end{array}$ & 99.1bC & $146.4 \mathrm{bB}$ & $337.4 \mathrm{bA}$ & $37.9 \mathrm{bC}$ & $68.2 \mathrm{bB}$ & $93.4 \mathrm{bA}$ & $79.9 \mathrm{bC}$ & $124.0 \mathrm{bB}$ & $387.2 \mathrm{bA}$ & $26.5 \mathrm{bC}$ & $41.2 \mathrm{bB}$ & $125.7 \mathrm{bA}$ \\
\hline $\begin{array}{l}\text { Fluxapyroxad }(0.058 \mathrm{~g} \\
\qquad \begin{array}{l}\left.\mathrm{L}^{-1}\right) \\
+ \text { Pyraclostrobin } \\
\left(0.116 \mathrm{~g} \mathrm{~L}^{-1}\right)\end{array}\end{array}$ & $129.1 \mathrm{aC}$ & $160.2 \mathrm{aB}$ & $388.9 \mathrm{aA}$ & $25.5 c \mathrm{C}$ & $55.6 \mathrm{cB}$ & 121.3aA & $89.7 \mathrm{aC}$ & $139.6 \mathrm{aB}$ & $447.2 \mathrm{aA}$ & $14.4 \mathrm{cC}$ & $27.4 \mathrm{aB}$ & $158.1 \mathrm{aA}$ \\
\hline $\begin{array}{c}\text { Metiram }\left(1.100 \mathrm{~g} \mathrm{~L}^{-1}\right) \\
+ \text { Pyraclostrobin } \\
\left(0.100 \mathrm{~g} \mathrm{~L}^{-1}\right)\end{array}$ & $126.9 \mathrm{aC}$ & 159.9aB & $389.0 \mathrm{aA}$ & $24.9 c C$ & $54.8 \mathrm{cB}$ & $118.9 \mathrm{aA}$ & $91.9 \mathrm{aC}$ & $141.3 \mathrm{aB}$ & $446.1 \mathrm{aA}$ & $11.9 \mathrm{cC}$ & $28.6 \mathrm{aB}$ & $162.0 \mathrm{aA}$ \\
\hline CV (\%) & 9.6 & 8.7 & 7.2 & 6.4 & 7.4 & 8.4 & 9.4 & 8.7 & 10.4 & 9.7 & 8.4 & 6.8 \\
\hline
\end{tabular}

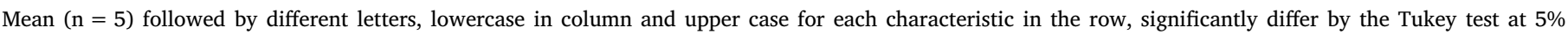
probability $(\mathrm{P} \leq 0.05)$. 50 DAT $=$ beginning of fruiting; $120 \mathrm{DAT}=$ end of harvest.

WUE.

The higher photosynthetic efficiency observed in plants treated with Flux + Pira is related to the higher $g_{s}$, which allowed greater $\mathrm{CO}_{2}$ diffusion to the substamatic chamber increasing $A_{\text {net }}$ and, consequently, the amount of photoassimilates produced, allowing greater plant development. The higher the $A_{\text {net }}$ value, the greater the photosynthetic gain, as the increase in liquid photosynthesis is a result of the increase of gross photosynthesis and reduction of respiration (Kluge et al., 2014).

In addition to this factor, it is noteworthy that both strobilurins and carboxamides act in the complex III (QoI) and complex II (SDHI) of the fungus mitochondrial respiration, respectively, irreversibly reducing the synthesis of NADH and ATP, blocking energy production (Kanungo and Joshi, 2014). Therefore, smaller AUPCDs, were observed in the plants treated with these fungicides, in contrast to the Inoc-control indicating that these molecules present efficient control during the germination of $A$. solani conidium due to their effect on the electron transport chain in the mitochondria, affecting the respiration of the fungus.
Some studies have indicated that these molecules act reversibly in the plant, causing transient blockade of electron transport in chloroplasts and mitochondria, limiting the production of ATP, which could lead to lower $g_{s}$ and reduction of $F_{v} / F_{m}$ values (Nason et al., 2007).

However, the opposite was observed in this experiment, and a possible explanation could be that there was a temporary reduction of cellular respiration due to the limited ATP production, in addition to the increase in the $\mathrm{CO}_{2}$ compensation point, which resulted in an increase in liquid photosynthesis, as already reported by Grossmann and Retzlaff (1997).

Plants development depends on the processes of cell division and expansion, which are sensitive to the concentration of assimilated $\mathrm{CO}_{2}$ (Tsutsumi et al., 2014). This justifies the lower development of Inoccontrol and Abs-control plants, because the reduction of the stomatal opening restricted the $\mathrm{CO}_{2}$ fixation rate, with consequent reduction of its concentration in the substamatic cavities and in the intercellular spaces $\left(C_{i}\right)$, reducing $A_{\text {net }}$, directly reflecting on the net photosynthesis of plants (Xu et al., 2015). The progress of the disease causes falls in photosynthetic efficiency, as it is a stressful factor. The plant reflects 


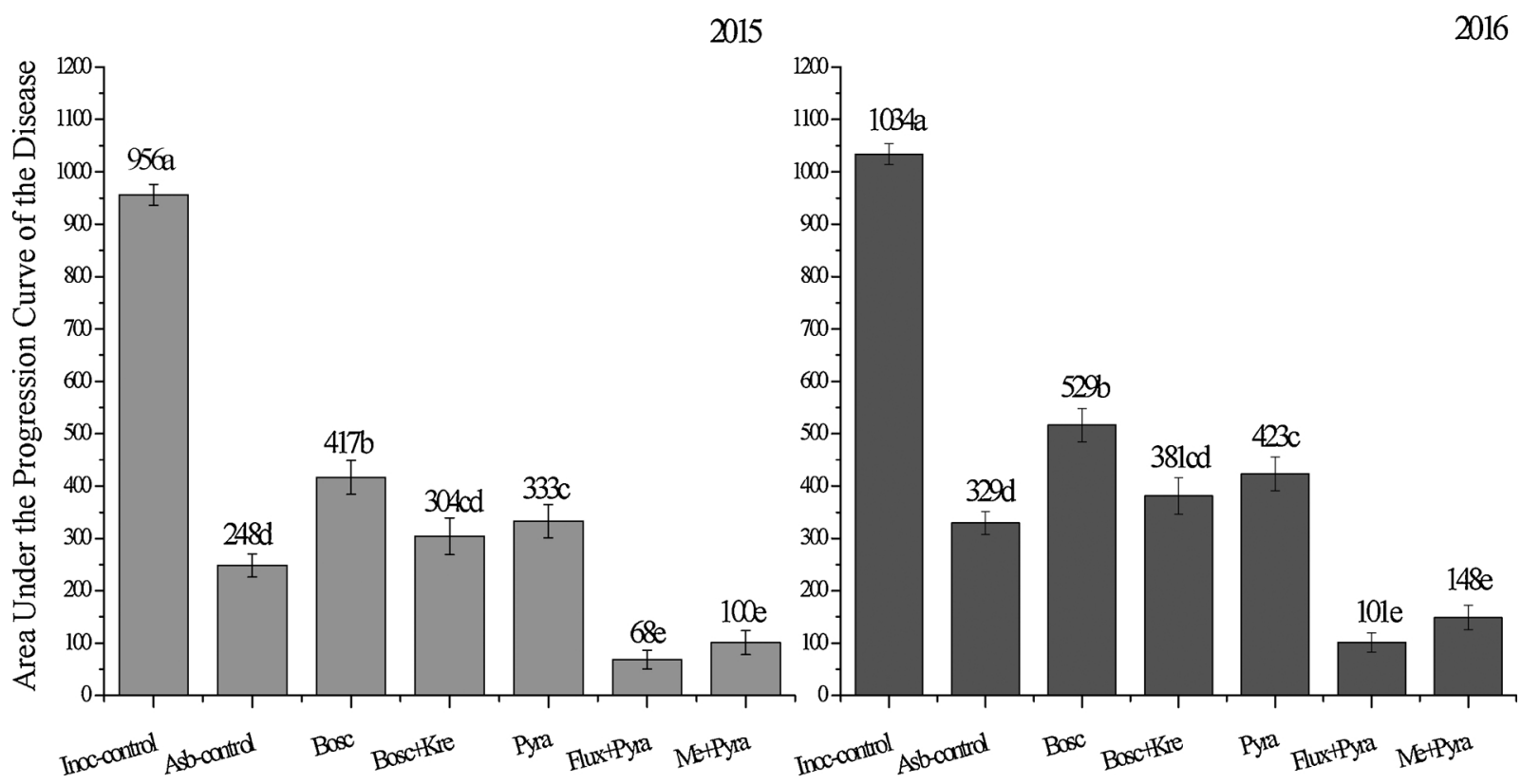

Fig. 6. Effect of different treatments with fungicides in the area under the progression curve of the disease (AUPCD), tested on the control of Alternaria solani in plants of hybrid tomato Conquistador, grown in greenhouse, in the years 2015 and 2016. Treatments: inoculated control (Inoc-control), absolute control (Abs-control), boscalid (Bosc), boscalid with kresoxim methyl (Bosc + Kre), pyraclostrobin (Pyra), fluxapyroxad with pyraclostrobin (Flux + Pyra) and metiram with pyraclostrobin $(\mathrm{Me}+$ Pyra). Means $(\mathrm{n}=10)$ followed by distinct letters differ by the Tukey test at the $1 \%$ probability level $(\mathrm{p}<0.01)$. Bars indicate and standard deviation of the mean.

Table 3

Total production (TP, $\mathrm{kg} \mathrm{m}^{-2}$ ), number of fruits (NF, fruits $\mathrm{m}^{-2}$ ), fresh fruit mass (FWF, $\mathrm{g}$ fruit ${ }^{-1}$ ) and percentage of non-commercial fruits (NCF, \%) of hybrid tomato plants Conquistador cv. cultivated in greenhouse and treated with different fungicides of physiological effects and inoculated with Alternaria solani, in the years 2015 and 2016.

\begin{tabular}{|c|c|c|c|c|}
\hline \multicolumn{5}{|l|}{2015} \\
\hline Treatments & $\begin{array}{l}\mathrm{TP} \\
\left(\mathrm{kg} \mathrm{m}^{-2}\right)\end{array}$ & $\begin{array}{l}\mathrm{NF} \\
\text { (fruits } \mathrm{m}^{-2} \text { ) }\end{array}$ & $\begin{array}{l}\text { FWF } \\
\left(\mathrm{g} \text { fruit }^{-1}\right)\end{array}$ & $\begin{array}{l}\mathrm{NCF}^{1} \\
(\%)^{*}\end{array}$ \\
\hline $\begin{array}{l}\text { Inoculated control } \\
\quad \text { (inoculum }+ \text { water) }\end{array}$ & $5.98 \mathrm{~d}$ & $52.00 \mathrm{~d}$ & $115.00 \mathrm{~d}$ & $30.20 \mathrm{~d}$ \\
\hline Absolute control (water) & $6.92 \mathrm{c}$ & $56.00 \mathrm{c}$ & $123.57 \mathrm{c}$ & $8.95 \mathrm{c}$ \\
\hline Boscalid $\left(0.075 \mathrm{~g} \mathrm{~L}^{-1}\right)$ & $9.34 \mathrm{~b}$ & $61.00 \mathrm{~b}$ & $153.11 \mathrm{~b}$ & $4.62 \mathrm{~b}$ \\
\hline $\begin{array}{l}\text { Boscalid }\left(0.100 \mathrm{~g} \mathrm{~L}^{-1}\right) \\
\quad+\text { Kresoxim methyl }\left(0.050 \mathrm{~g} \mathrm{~L}^{-1}\right)\end{array}$ & $9.85 \mathrm{~b}$ & $64.00 \mathrm{~b}$ & $153.91 \mathrm{~b}$ & $5.21 \mathrm{~b}$ \\
\hline Pyraclostrobin $\left(0.100 \mathrm{~g} \mathrm{~L}^{-1}\right)$ & $9.77 \mathrm{~b}$ & $63.00 \mathrm{~b}$ & $155.08 \mathrm{~b}$ & $4.99 \mathrm{~b}$ \\
\hline $\begin{array}{l}\text { Fluxapyroxad }\left(0.058 \mathrm{~g} \mathrm{~L}^{-1}\right) \\
\quad+\text { Pyraclostrobin }\left(0.116 \mathrm{~g} \mathrm{~L}^{-1}\right)\end{array}$ & $12.21 \mathrm{a}$ & $67.00 \mathrm{a}$ & $182.24 a$ & $2.84 a$ \\
\hline $\begin{array}{l}\text { Metiram }\left(1.100 \mathrm{~g} \mathrm{~L}^{-1}\right) \\
\quad+\text { Pyraclostrobin }\left(0.100 \mathrm{~g} \mathrm{~L}^{-1}\right)\end{array}$ & $11.87 \mathrm{a}$ & $66.00 \mathrm{a}$ & $179.85 a$ & $2.56 \mathrm{a}$ \\
\hline CV (\%) & 16.54 & 14.23 & 10.78 & 9.56 \\
\hline \multicolumn{5}{|l|}{2016} \\
\hline Treatmentscheme & $\begin{array}{l}\mathrm{TP} \\
\left(\mathrm{kg} \mathrm{m}^{-2}\right)\end{array}$ & $\begin{array}{l}\mathrm{NF} \\
\left(\text { fruits } \mathrm{m}^{-2} \text { ) }\right.\end{array}$ & $\begin{array}{l}\text { FWF } \\
\left(\text { g fruit }^{-1}\right)\end{array}$ & $\begin{array}{l}\text { NCF } \\
(\%)\end{array}$ \\
\hline $\begin{array}{l}\text { Inoculated control } \\
\text { (inoculum + water) }\end{array}$ & $5.21 \mathrm{~d}$ & $48.00 \mathrm{~d}$ & $108.54 \mathrm{~d}$ & $27.08 \mathrm{~d}$ \\
\hline Absolute control (water) & $6.08 \mathrm{c}$ & $52.00 \mathrm{c}$ & $116.83 \mathrm{c}$ & $9.61 \mathrm{c}$ \\
\hline Boscalid $\left(0.075 \mathrm{~g} \mathrm{~L}^{-1}\right)$ & $8.96 \mathrm{~b}$ & $61.00 \mathrm{~b}$ & $146.85 \mathrm{~b}$ & $4.91 \mathrm{~b}$ \\
\hline $\begin{array}{l}\text { Boscalid }\left(0.100 \mathrm{~g} \mathrm{~L}^{-1}\right) \\
\quad+\text { Kresoxim methyl }\left(0.050 \mathrm{~g} \mathrm{~L}^{-1}\right)\end{array}$ & $9.03 \mathrm{~b}$ & $62.00 \mathrm{~b}$ & $145.56 \mathrm{~b}$ & $6.45 \mathrm{~b}$ \\
\hline Pyraclostrobin $\left(0.100 \mathrm{~g} \mathrm{~L}^{-1}\right)$ & $9.15 \mathrm{~b}$ & $60.00 \mathrm{~b}$ & $152.53 \mathrm{~b}$ & $5.00 \mathrm{~b}$ \\
\hline $\begin{array}{l}\text { Fluxapyroxad }\left(0.058 \mathrm{~g} \mathrm{~L}^{-1}\right) \\
\quad+\text { Pyraclostrobin }\left(0.116 \mathrm{~g} \mathrm{~L}^{-1}\right)\end{array}$ & $11.71 \mathrm{a}$ & $65.00 \mathrm{a}$ & $180.18 \mathrm{a}$ & $3.07 a$ \\
\hline $\begin{array}{l}\text { Metiram }\left(1.100 \mathrm{~g} \mathrm{~L}^{-1}\right) \\
\quad+\text { Pyraclostrobin }\left(0.100 \mathrm{~g} \mathrm{~L}^{-1}\right)\end{array}$ & $11.22 \mathrm{a}$ & $64.00 \mathrm{a}$ & $175.36 \mathrm{a}$ & $1.56 \mathrm{a}$ \\
\hline CV (\%) & 14.23 & 9.56 & 12.6 & 10.4 \\
\hline
\end{tabular}

${ }^{1} \mathrm{NCF}=$ discard of fruits smaller than $40 \mathrm{~mm}$ in diameter and with defects (rot, deformed, physiological disorders etc.). * Data transformed into arc sine of $\sqrt{\mathrm{x}}$ (\%). Means $(n=5)$ followed by the same letter in the columns do not significantly differ from each other by the Tukey test at $5 \%$ probability $(P \leq 0.05)$. 
this damage by the concentration of pigments or by the higher fluorescence emission of chlorophyll $a$ (Brestic and Zirvcak, 2013).

The fact that gas exchange measurements and chlorophyll $a$ fluorescence analyses were carried out simultaneously helped understanding the severity of the damage caused by the presence of pathogen A. solani. Studies have indicated that any change in photosynthetic rate or heat dissipation will reflect in higher fluorescence emission (Rousseau et al., 2013), allowing identifying the sanity of the photosynthetic apparatus of the plant at the moment of evaluation. Changes in the emission kinetics of chlorophyll $a$ fluorescence can detect and infer the presence of damage in the photosynthetic apparatus due to damage caused by stressors (Yusuf et al., 2010).

The $F_{v} / F_{m}$ values observed in plants treated with the different fungicides tested showed that they were healthy, being in agreement with studies carried out by Björkman and Demming (1987), who evaluated different $\mathrm{C}_{3}$ cycle species and observed typical $F_{v} / F_{m}$ values in healthy leaves and, under adequate lighting conditions, around 0.83 . Already values below this standard indicate that the plant presents some type of stress, causing damages to its photosynthetic apparatus, as observed in Inoc-control and Abs-control plants.

Stress conditions are detected by the decrease in the $F_{v} / F_{m}$ ratio (Baker, 2008; Rousseau et al., 2013), reflecting lower photosynthetic capacity and photochemical efficiency (Casierra-Posada et al., 2011). Species of the genus Alternaria produce proliferative toxins, which facilitate their necrotrophic life, causing damage to plant tissues (Lawrence et al., 2008). Therefore, in addition to the decrease in the $F_{v} /$ $F_{m}$ ratio, the presence of the pathogen $A$. solani also caused the unbalance between PSII and PSI photosystems, as can be observed by the lower ETR values in Inoc-control plants. This could trigger the pseudocyclic transport of electrons (Mehler's reaction) to form superoxide anion $\left(\cdot \mathrm{O}_{2}{ }^{-}\right)$and other reactive oxygen species (ROS), such as $\cdot \mathrm{O}_{2}{ }^{-}$ (Karuppanapandian et al., 2011), intensifying damage to the photosynthetic apparatus.

Plants submitted to the application of strobilurin and carboxamides presented higher $F_{v}$ values, effective quantum yield of PSII, Y(II) and ETR when compared to controls, with emphasis on Flux + Pyra treatment, indicating greater capacity to assimilate $\mathrm{CO}_{2}$, since this parameter indicates the transference capacity of PSII and electron between PSII and PSI for the generation of $\mathrm{NADPH}_{2}$ and ATP. Culminating in higher photosynthetic efficiency due to high ETR values (Baker, 2008), as verified in the gas exchange parameters at $34 \mathrm{DAT}$, in the vegetative phase, as at 94 DAT in the reproductive phase.

The concentration of photosynthetic pigments was higher in plants treated with strobilurin and carboxamides, indicating that the increase in photosynthetic efficiency observed in these treatments, has a great relation with the amount of chlorophyll $a$ and $b$, and carotenoids present in PSI and PSII (Casierra-Posada and Peña-Olmos, 2015). Resulting in greater absorption of sunlight and, consequently, greater ETR values (Rodrigues et al., 2016), as observed for Flux + Pyra, followed by $\mathrm{Me}+$ Pyra treatments. Increases in the content of photosynthetic pigments were also reported in tomato with the application of pyraclostrobin plus boscalid (Ramos et al., 2015) and coffee with application of pyraclostrobin (Honorato Júnior et al., 2015), reflecting higher photosynthetic efficiency of plants, in addition to the increase of the repair and protection of the photosynthetic apparatus by carotenoids (Nisar et al., 2015).

The highest content of photosynthetic pigments reflected in the efficiency of the photochemical metabolism, being strongly influenced by the activity of the NR enzyme, which is the key enzyme in the regulation of nitrogen metabolism (Viana and Kiehl, 2010), main constituent of the chlorophyll molecule (Kluge et al., 2014). In fact, the activity of the NR enzyme was influenced by the application of strobilurin and carboxamides, especially Flux + Pyra and Me + Pyra treatments, with enzyme expression peaks occurring at 50,65 and 80 DAT (transition between vegetative phase and early reproductive period) and at 95 and 110 DAT (fruit growth and maturation phase).
The effect of NR enzyme activity during the plant life cycle was observed in soybean (Soares et al., 2011), corn (Barbosa et al., 2011) and Japanese cucumber plants (Amaro et al., 2018), related to the phases of higher demand for nitrogen by the plant. Some studies have demonstrated that there is an increase in biomass and production, even in plants that are not affected by fungi, so they are interesting agricultural practices in the agricultural scenario in the management of nitrogen fertilization (Kanungo and Joshi, 2014).

It was observed that at 50 and 120 DAT, regardless of treatment, all plants presented effective translocation of carbohydrates to fruits. However, the highest concentrations of total sugars and reducing sugars were observed in fungicide-treated plants, especially Flux + Pyra and $\mathrm{Me}+$ Pyra treatments. It is evident that productivity increases in tomato plants treated with such fungicides due to the better physiological performance that allowed greater synthesis and translocation of carbohydrates to fruits. Evaluating the application of pyraclostrobin and boscalide, isolated and combined with other chemicals in tomato plants, Ramos et al. (2015) also observed that in all treatments, the concentrations of total and reducing sugars were higher than in control plants. In addition to verifying that the fruit was statistically superior to leaves and stem, evidencing that these treatments are effective regarding the greater translocation of these sugars, promoting greater tissue development, and increasing tissue drainage capacity.

Studies have shown that strobilurins, such as pyraclostrobin, alter the hormonal balance of the plant, promoting the synthesis of auxins and abscisic acid (ABA) and reducing the ethylene production (Kanungo and Joshi, 2014). A possible hypothesis in this study may be related to the improvement in the hormonal balance, influencing the regulation of source-drain relations, promoting greater drainage tissue growth and, thus, influencing the translocation of photoassimilates to these organs (Albacete et al., 2014). Another possible effect of these substances on transport and accumulation of sugars was identified by Van Dingenen et al. (2017) in A. thaliana plants treated with kresoximmethyl (strobilurin). The authors observed that the transcribed genes involved in the transport of sugars were differentially expressed in plants treated with strobilurins, although no difference in sucrose content was observed. However, carbohydrates translocated at long distances in the phloem are non-reducing sugars, because they are less reactive (Dinant and Lemoine, 2010). Sucrose is the sugar predominantly translocated via phloem, but other mobile sugars as raffinose and stachyose are also present, in addition to sugar alcohols such as sorbitol and mannitol (Van Bel and Hess, 2008).

At the end of the crop cycle (120 DAT) Flux + Pyra and Me + Pyra treatments presented the highest concentrations of total sugars in all evaluated organs. As a result, these plants presented higher fruit yield and, concurrently, more commercial fruits. These results show that the application of strobilurins and carboxamides increased tomato productivity and are consistent with Giuliani et al. (2010) and Cantore et al. (2016), who reported that the application of azoxystrobin and pyraclostrobin, respectively, in tomato plants promoted higher marketable fruit yield. Previous studies have also demonstrated productivity increases by these fungicides in other crops such as grapevine (Diaz-Espejo et al., 2012), soy (Joshi et al., 2014), beans (Jadoski et al., 2015), corn (Shetley et al., 2015), carrot (Colombari et al., 2015) and Japanese cucumber (Amaro et al., 2018). Such productive gains are associated with side effects on plant physiology and improved disease control efficacy (Diaz-Espejo et al., 2012). The application of fungicides that promote physiological effects can be considered as part of managements that maximize the photosynthetic process and provide greater amount of energy to increase plant productivity.

\section{Conclusion}

Based on the results obtained and the experimental conditions, it could be concluded that the applications of boscalid, boscalid with kresoxim methyl, pyraclostrobin, fluxapyroxad with pyraclostrobin and 
metiram with pyraclostrobin provided positive effects on the photosynthetic efficiency and yield of tomato plants, besides efficient control of $A$. solani. The highest fruit development and yield was observed in plants treated with fluxapyroxad with pyraclostrobin, followed by metiram with pyraclostrobin, which showed high photochemical yield due to the higher levels of photosynthetic pigments, high activity of the nitrate reductase enzyme and increased synthesis and translocation of photoassimilates.

\section{Acknowledgments}

The authors thank the Jessica Caroline Miri for the substantial help with the conduction of this experiment.

\section{References}

Albacete, A.A., Martínez-Andújar, C., Pérez-Alfocea, F., 2014. Hormonal and metabolic regulation of source-sink relations under salinity and drought: from plant survival to crop yield stability. Biotechnol. Adv. 32 (1), 12-30. https://doi.org/10.1016/j. biotechadv.2013.10.005.

Amaro, A.C.E., Ramos, A.R.P., Macedo, A.C., Ono, E.O., Rodrigues, J.D., 2018. Effects of the fungicides azoxystrobin, pyraclostrobin and boscalid on the physiology of Japanese cucumber. Sci. Hortic. 228 (26), 66-75. https://doi.org/10.1016/j.scienta. 2017.10.016.

Bag, M.K., Yadav, M., Mukherjee, A.K., 2016. Bioefficacy of strobilurin based fungicides against rice sheath blight disease. Transcriptomics 4 (128), 1-2 https://www.omicsonline.org/.../bioefficacy-of-strobilurin-based-f....

Baker, N.R., 2008. Chlorophyll fluorescence as a probe of photosynthesis in vivo. Annu. Rev. Plant Biol. 59, 89-113. https://www.ncbi.nlm.nih.gov/pubmed/18444897.

Barbosa, K.A., Fagan, E.B., Casaroli, D., Canedo, S.D.C., Teixeira, W.F., 2011. Aplicação de estrobilurina na cultura do milho: alterações fisiológicas e bromatológicas 2 . Revista do Centro Universitário de Patos de Minas, pp. 20-26. http:// revistaagrociencias. unipam.edu.br/documents/57126/58774/aplicacao de estrobilurina_artigo.pdf.

Björkman, O., Demming, B., 1987. Photon yield of $\mathrm{O}_{2}$ evolution and chlorophyll fluorescence characteristics at 77k among vasculas plants of diverse origins. Planta 170 (4), 489-504. https://link.springer.com/article/10.1007/BF00402983.

Brestic, M., Zirvcak, M., 2013. PSII fluorescence techniques for measurement of drought and high temperature stress signal in crop plants: protocols and applications. In: Rout, G.R., Das, A.B. (Eds.), Molecular Stress Physiology of Plants. Springer Dordrecht, Bhubaneswar, India, pp. 87-133.

Campbell, C.L., Madden, L.V., 1990. Introduction to Plant Disease Epidemiology. John Wiley \& Sons, pp. 560.

Cantore, V., Lechkar, O., Karabulut, E., Sellami, M.H., Albrizio, R., Boari, F., Stellacci, A.M., Todorovic, M., 2016. Combined effect of deficit irrigation and strobilurin application on yield, fruit quality and water use efficiency of "cherry" tomato (Solanum lycopersicum L.). Agric. Water Manag. 167 (31), 53-61. https://doi.org/10.1016/j. agwat.2015.12.024.

Casierra-Posada, F., Peña-Olmos, J.E., 2015. Modificaciones fotomorfogénicas inducidas por la calidad de la luz en plantas cultivadas. Revista de la Academia Colombiana de Ciencias Exactas, Físicas y Naturales 39, 84-92. https://doi.org/10.18257/raccefyn. 276.

Casierra-Posada, F., Peña-Olmos, J.E., Ulrichs, C., 2011. Growth and photochemical efficiency of Photosystem II in strawberry plants (Fragaria sp.) affected by the light quality: agronomic implications. Revista Actualidad Divulgación Científica 14 (2), 43-53 www.scielo.org.co/scielo.php?script $=$ sci_arttext\&pid $=$ S0123...

Colombari, L.F., Baldini, L.F.G., Baldini, V., Cardoso, A.I.I., Goto, R., 2015. Efeito fisiológico de fungicidas sistémicos em parâmetros agronómicos da cenoura. Revista de Ciências Agrárias 38 (3), 366-371. http://www.scielo.mec.pt/pdf/rca/v38n3/ v38n3a11.pdf.

de Azevedo, L.A.S., 1997. Manual de quantificação de doenças de plantas. Luiz Azevedo, São Paulo, pp. 51-102.

Debona, D., Nascimento, K.J.T., Gomes, J.G.O., Aucique-Perez, C.E., Rodrigues, F.A., 2016. Physiological changes promoted by a strobilurin fungicide in the rice-Bipolaris oryzae interaction. Pestic. Biochem. Physiol. 130, 8-16. https://doi.org/10.1016/j. pestbp. 2015.12.006.

Diaz-Espejo, A., Cuevas, M.V., Ribas-Carbo, M., Flexas, J., Martorell, S., Fernández, J.E., 2012. The effect of strobilurins on leaf gas exchange, water use efficiency and ABA content in grapevine under field conditions. J. Plant Physiol. 169 (4), 379-386. https://www.ncbi.nlm.nih.gov/pubmed/22209165.

Dinant, S., Lemoine, R., 2010. The phloem pathway: new issues and old debates. Comptes Rendus Biologies 333 (4), 307-319. https://www.ncbi.nlm.nih.gov/pubmed/ 20371105 .

Embrapa - Empresa Brasileira de Pesquisa Agropecuária, 2013. Sistema brasileiro de classificação de solos, 3 ed. Embrapa Solos, Rio de Janeiro, pp. 353.

Fagan, E.B., Dourado Neto, D., Vivian, R., Franco, R.B., Yeda, M.P., Massignam, L.F., Martins, K.V., 2010. Efeito da aplicação de piraclostrobina na taxa fotossintética, respiração, atividade da enzima nitrato redutase e produtividade de grãos de soja. Bragantia 69 (4), 771-777. https://doi.org/10.1590/S0006-87052010000400001.

Frac Code List (C)*, 2017. Fungicides Sorted by Mode of Action (including FRAC Code Numbering). pp. 1-12. http://www.frac.info/.
Garcia, I.S., Souza, A., Barbedo, C.J., Dietrich, S.M.C., Figueiredo-Ribeiro, R.C.L., 2006. Changes in soluble carbohydrates during storage of Caesalpinia echinata LAM. (Brazilwood) seeds, an endangered leguminous tree from the Brazilian Atlantic Forest. Braz. J. Biol. 66, 739-745. https://www.ncbi.nlm.nih.gov/pubmed/ 16906306.

Giuliani, M.M., Nardella, E., Gatta, G., De Caro, A., Quitadamo, M., 2010. Processing tomato cultivated under water deficit conditions: the effect of azoxystrobin. Acta Hortic. 914, 287-294. www.actahort.org/books/914/914_52.htm.

Grossmann, K., Retzlaff, G., 1997. Bioregulatory effects of the fungicidal strobilurin kresoxim-methyl in wheat (Triticum aestivum). Pestic. Sci. 50, 11-20. https://doi. org/10.1002/(SICI)1096-9063(199705)50:1 < 11::AID-PS556\&3.0.CO;2-8.

Honorato Júnior, J., Zambolim, L., Aucique-Pérez, C.E., Resende, R.S., Rodrigues, F.A., 2015. Photosynthetic and antioxidative alterations in coffee leaves caused by epoxiconazole and pyraclostrobin sprays and Hemileia vastatrix infection. Pestic. Biochem. Physiol. 123, 31-39. https://doi.org/10.1016/j.pestbp.2015.01.016.

Jadoski, C.J., Rodrigues, J.D., Soratto, R.P., Dos Santos, C.M., Ribeiro, E., 2015. Ação fisiológica da piraclostrobina na assimilação de $\mathrm{CO}_{2}$ e enzimas antioxidantes em plantas de feijão condicionado em diferentes tensões de água no solo. Irriga 20 , 319-333. https://doi.org/10.15809/irriga.2015v20n2p319.

Joshi, J., Sharma, S., Guruprasad, K.N., 2014. Foliar application of pyraclostrobin fungicide enhances the growth, rhizobial-nodule formation and nitrogenase activity in soybean (var. JS-335). Pestic. Biochem. Physiol. 114, 61-66. https://www.ncbi.nlm. nih.gov/pubmed/25175651.

Junqueira, V.B., Costa, A.C., Boff, T., Müller, C., Mendonça, M.A.C., Batista, P.F., 2017 Pollen viability, physiology, and production of maize plants exposed to pyraclostrobin + epoxiconazole. Pestic. Biochem. Physiol. 137, 42-48. https://doi.org/10. 1016/j.pestbp.2016.09.007.

Kanungo, M., Joshi, J., 2014. Impact of Pyraclostrobin (F-500) on crop plants. Plant Sci. Today 1, 174-178. https://doi.org/10.14719/pst.2014.1.3.60.

Karuppanapandian, T., Moon, J.C., Kim, C., Manoharan, K., Kim, W., 2011. Reactive oxygen species in plants: their generation, signal transduction, and scavenging mechanisms. Aust. J. Crop Sci. 5, 709-725. https://search.informit.com.au/ documentSummary; dn = 282079847301776;res = IELHSS.

Kluge, R.A., Tezotto-Uliana, J.V., Silva, P.P., 2014. Aspectos fisiológicos e ambientais da fotossíntese. Revista Virtual de Química 7, 56-73. https://doi.org/10.5935/19846835.20150004.

Lawrence, C.B., Mitchell, T.K., Craven, K.D., Cho, Y.R., Cramer, R.A., Kim, K.H., 2008. At death's door: alternaria pathogenicity mechanisms. Plant Pathol. J. 24, 101-111. http://www.koreascience.or.kr/article/ArticleFullRecord.jsp?cn =E1PPBG_2008 v24n2_101.

Lichtenthaler, H.K., Wellburn, A.R., 1983. Determinations of total carotenoids and chlorophylls $a$ and $b$ of leaf extracts in different solvents. Biochem. Soc. Trans. 11, 591-592. www.biochemsoctrans.org/content/11/5/591.

Lima, A.D.S., Reffatti, M.T.N., Juncos, M.C., Burbulhan, T., Martikoski, L., 2009. Efeito fisiológico de fungicida pyraclostrobin e tratamento de sementes na cultura do milho. Pesquisa Aplicada Agrotecnologia 2, 113-120. http://revistas. unicentro.br/index. $\mathrm{php} / \mathrm{repaa} / \mathrm{article} /$ download/1507/1370.

Lima, J.D., Moraes, W.D.S., Silva, S.H.M.G.D., 2012. Respostas fisiológicas em mudas de banananeira tratadas com estrobilurinas. Semina: Ciências Agrárias 33, 77-86. www. redalyc.org/html/4457/445744111008/.

Macedo, A.C., Amaro, A.C.E., Ramos, A.R.P., Ono, E.O., Rodrigues, J.D., 2017. Strobilurin and boscalid in the quality of net melon fruits. Semina: Ciências Agrárias. 38, 543-550. https://doi.org/10.5433/1679-0359.2017v38n2p543.

Mahoney, K.J., Gillard, C.L., 2014. Plant health and yield of dry bean not affected by strobilurin fungicides under disease-free or simulated hail conditions. Can. J. Plant Sci. 94, 1385-1389. https://doi.org/10.1139/CJPS-2014-159.

Miller, G.L., 1959. Use of dinitrosalicylic acid reagent for determination of reducing sugar. Anal. Chem. 31, 426-428. https://pubs.acs.org/doi/abs/10.1021/ ac60147a030 ?journalCode $=$ ancham.

Morris, D.L., 1948. Quantitative determination of carbohydrates with dreywood's anthrone reagent. Science 107, 254-255. https://www.ncbi.nlm.nih.gov/pubmed 17814729.

Nason, M.A., Farrar, J., Bartlett, D., 2007. Strobilurin fungicides induce changes in photosynthetic gas exchange that do not improve water use efficiency of plants grown under conditions of water stress. Pest Manag. Sci. 63, 1191-1200. https://doi. org/10.1002/ps.1443.

Nisar, N., Li, L., Lu, S., Khin, N.C., Pogson, B.J., 2015. Carotenoid metabolism in plants. Mol. Plant 8, 68-82. https://www.ncbi.nlm.nih.gov/pubmed/25578273.

Petit, A.N., Fontaine, F., Vatsa, P., Clément, C., Vaillant-Gaveau, N., 2012. Fungicide impacts on photosynthesis in crop plants. Photosyn. Res. 111, 315-326. https://link. springer.com/article/10.1007/s11120-012-9719-8.

Popov, E.G., Talanov, A.V., Kurets, V.K., Drozdov, S.N., 2003. Effect of temperature on diurnal changes in $\mathrm{CO}_{2}$ exchange in intact cucumber plants. Russ. J. Plant Physiol. 50, 178-182. https://link.springer.com/article/10.1023/A\%3A1022964928958.

R Development Core Team, 2016. R: a Language and Environment for Statistical Computing. ISBN 3-900051-07-0, URL. R Foundation for Statistical Computing, Vienna, Austria. http://www.R-project.org/.

Ramos, R.P., Amaro, A.C.E., Macedo, A.C., Souza, E.R., Rodrigues, J.D., Ono, E.O., 2015 Acúmulo de carboidratos no desenvolvimento de tomateiro tratado com produtos químicos. Semina: Ciências Agrárias 36, 705-718. https://doi.org/10.5433/1679. 0359.2015v36n2p705.

Rodrigues, C.R., Rodrigues, T.M., Luz, J.M.Q., Sousa, V.B.F., Sousa, J.B., Nunes, A.C.P., Trindade, P.R., 2016. Clorofila $a$ e $b$ de tomateiro tratado com silicato de potássio e fungicida. Glob. Sci. Technol. 9, 54-64. https://rv.ifgoiano.edu.br/periodicos/index. $\mathrm{php/gst/article/view/806.}$

Rousseau, C., Belin, E., Bove, E., Rousseau, D., Fabre, F., Berruyer, R., Guillaumés, J., 
Manceau, C., Jacques, M.A., Boureau, T., 2013. High throughput quantitative phenotyping of plant resistance using chlorophyll fluorescence image analysis. Plant Methods 9, 1-13. https://doi.org/10.1186/1746-4811-9-17.

Shetley, J., Nelson, K.A., Stevens, W.G., Dunn, D., Burdick, B., Motavalli, P.P., English, J.T., Dudenhoeffer, C.J., 2015. Corn yield response to pyraclostrobin with foliar fertilizers. J. Agric. Sci. 7, 18-34. https://doi.org/10.5539/jas.v7n7p18.

Soares, L.H., Fagan, E.B., Casaroli, D., Andrade, D.M.D., Soares, A.L., Martins, K.V., Rocha, F.J.D., 2011. Aplicação de diferentes estrobilurinas na cultura da soja. Revista da FZVA 18, 78-97. http://revistaseletronicas.pucrs.br/ojs/index.php/fzva/article/ view/8216.

Streeter, J.G., Bosler, M.E., 1972. Comparison of in vitro and in vivo assays for nitrate reductase in soybean leaves. Plant Physiol. 49, 448-450. https://www.ncbi.nlm.nih. gov/pmc/articles/PMC365983/.

Swoboda, C., Pedersen, P., 2009. Effect of fungicide on soybean growth and yield. Agron. J. 101, 352-356. https://dl.sciencesocieties.org/publications/aj/pdfs/101/2/352.

Töfoli, J.G., Domingues, R.J., Ferrari, J.T., 2014. Requeima e mancha de alternaria na culturas da batata e tomate: Divulgação técnica 76. Instituto Biológico, pp. 41-50. https://www.researchgate.net/profile/Jesus_Toefoli/publication/272176546 Requeima_e_pinta_preta_na_cultura_da_batata_importancia_caracteristicas_e_manejo sustentavel/links/54de19770cf23bf2043a4cfd/Requeima-e-pinta-preta-na-culturada-batata-importancia-caracteristicas-e-manejo-sustentavel.pdf.

Tsialtas, J.T., Theologidou, G.S., Karaoglanidis, G.S., 2017. Effect of pyraclostrobin on disease control, leaf physiology, seed yield and quality of sunflower. Crop. Prot. 99, 151-159. https://doi.org/10.1016/j.cropro.2017.05.022.

Tsumanuma, G.M., Carvalho, S.J.P.D., Fancelli, A.L., Bernardes, M.S., Rodrigues, M.A.T., Begliomini, E., 2010. Crescimento dedois cultivares de soja submetidos a aplicações de herbicidas e fungicidas. Rev. Ceres 57, 742-750. http://www.ceres.ufv.br/ojs/ index.php/ceres/article/view/3563.
Tsutsumi, K., Konno, M., Miyazawa, S.I., Miyao, M., 2014. Sites of action of elevated $\mathrm{CO}_{2}$ on leaf development in rice: discrimination between the effects of elevated $\mathrm{CO}_{2}$ and nitrogen deficiency. Plant Cell Physiol. 55, 258-268. https://www.ncbi.nlm.nih.gov/ pubmed/24406628.

Van Bel, A.J.E., Hess, P.H., 2008. Hexoses as phloem transport sugars: the end of a dogma? J. Exp. Bot. 59, 261-272. https://www.ncbi.nlm.nih.gov/pubmed/ 18332226.

Van Dingenen, J., Antoniou, C., Filippoi, P., Pollier, J., Gonzalez, N., Dhondt, S., Goossens, A., Fotopoulos, V., Inzé, D., 2017. Strobilurins as growth-promoting compounds: how Stroby regulates Arabidopsis leaf growth. Plant Cell Environ. 40, 1748-1760. https://doi.org/10.1111/pce.12980.

Viana, E.M., Kiehl, J.C., 2010. Doses de nitrogênio e potássio no crescimento do trigo. Bragantia 69, 975-982. https://doi.org/10.1590/S0006-87052010000400024.

Von Caemmerer, S., Farquhar, G.D., 1981. Some relationships between the biochemistry of photosynthesis and the gas exchange of leaves. Planta 153, 376-387. https://link springer.com/article/10.1007/BF00384257.

Xu, Z., Jiang, Y., Zhou, G., 2015. Response and adaptation of photosynthesis, respiration, and antioxidant systems to elevated $\mathrm{CO}_{2}$ with environmental stress in plants. Front. Plant Sci. 6, 1-17. https://www.ncbi.nlm.nih.gov/pubmed/26442017.

Yemm, E.W., Willis, A.J., 1954. The estimation of carbohydrates in plant extracts by anthrone. Biochem. J. 57, 508-514. https://www.ncbi.nlm.nih.gov/pmc/articles/ PMC1269789/.

Yusuf, M.A., Kumar, D., Rajwanshi, R., Strasser, R.J., Tsimillimichael, M., Govindjee, Sarin, N.B., 2010. Overexpression of y-totopherol methyl transferase gene in transgenic Brassica juncea plants alleviates abiotic stress: physiological and chlorophyll $a$ fluorescence measurements. Biochim. Biophys. Acta (BBA)-Bioenergetics 1797, 1428-1438. https://www.ncbi.nlm.nih.gov/pubmed/20144585. 